Max-Planck-Institut für demografische Forschung

Max Planck Institute for Demographic Research

Konrad-Zuse-Strasse 1 - D-18057 Rostock = Germany = Tel +49 (0) 3812081 - 0 - Fax +49 (0) 3812081 - 202 - www.demogr.mpg.de

MPIDR Working Paper WP 2020-001 I January 2020

https://doi.org/10.4054/MPIDR-WP-2020-001

\title{
Analysis of Latin American fertility in terms of probable social classes
}

Andres Castro I castro@demogr.mpg.de

This working paper has been approved for release by: Mathias Lerch (lerch@demogr.mpg.de),

Deputy Head of the Laboratory of Fertility and Well-Being.

(ㄷ) Copyright is held by the authors.

Working papers of the Max Planck Institute for Demographic Research receive only limited review. Views or opinions expressed in working papers are attributable to the authors and do not necessarily reflect those of the Institute. 


\title{
Analysis of Latin American fertility in terms of probable social classes
}

\begin{abstract}
Theories of demographic change have not paid enough attention to how factors associated with fertility decline play different roles across social classes that are defined multidimensionally. I use a multidimensional definition of social class along with information on the reproductive histories of women born between 1920 and 1965 in six Latin American countries to show the following: the enduring connection between social stratification and fertility differentials, the concomitance of diverse fertilitydecline trajectories by class, and the role of within- and between-class social distances in promoting/preventing ideational change towards the acceptance of lower fertility. These results enable me to revisit the scope of theories of fertility change, and to provide an explanatory narrative centred on empirically-constructed social classes (probable social classes) and the macro- and micro-level conditions that influenced their life courses. I use 21 census samples collected between 1970 and 2005 in Bolivia, Brazil, Chile, Colombia, Mexico, and Paraguay.
\end{abstract}

Keywords: fertility, social class, Latin America 


\section{Introduction}

During the second half of the $20^{\text {th }}$ century, the total fertility rate for Latin America dropped from 5.9 to 2.6 children per woman (Guzmán, 1996; Guzmán et al., 2006). This decline is associated with a decreasing demand for children, along with an increase in the ability of couples to practice birth control effectively. Five macro developmental processes (forces of modernisation) are associated with these trends: (1) rising availability of modern contraceptive methods, (2) increasing educational attainment for women, (3) growing female labour force participation, (4) on-going urbanisation (mainly due to rural-to-urban migration), and (5) improving mortality conditions (Castro Martin and Juarez, 1995; Bongaarts, 2003). The mean age at first birth remained stable during this same period (Palloni, 1990; Bongaarts, Mensch and Blanc, 2017). While less educated women were accelerating the transition to childbearing, highly educated women were postponing the first birth. (Juarez and Gayet, 2014).

Strong correlations between fertility (intensity and timing) and the forces of modernisation—at the individual and the country level—have led scholars to propose theories that tie lower and delayed fertility to improving material conditions (Hirschman, 1994; Mason, 1997; Myrskylä, Kohler and Billari, 2009; Kohler, 2010; Pesando and GFC-team, 2019). Other proposed theoretical frameworks have attributed these trends to non-material factors, such as institutional arrangements, social networks, systems of beliefs, cognitive structures, and social norms (McNicoll, 1980; Cleland and Wilson, 1987; Bachrach and Morgan, 2013). According to these theories, the extent to which people use material means to limit family size (e.g., delayed marriage, withdrawal, or modern contraception) can vary from one group to another depending on their cultural setting. Once a cultural change has occurred among one of the leading groups, it can spread to others through social interaction in a process that is sometimes referred to as ideational change (Bongaarts and Watkins, 1996). 
These theoretical frameworks have produced various explanations for long-lasting declines in family size (van de Kaa, 1996), including the quality-quantity trade-off, the higher opportunity cost for women in the labour market, the reversal in the inter-generational flows of financial support, and the cultural transmission of low-fertility norms (Becker, 1981; Caldwell, 1982; Bongaarts, 2003; Lee, 2003; Skirbekk, 2008; Shenk et al., 2013). It is my view, however, that none of these explanations pays enough attention to how the factors that have been shown to contribute to variation in fertility and in the timing of childbearing play different roles across social classes that are defined multidimensionally.

As class structures evolved during the $19^{\text {th }}$ and $20^{\text {th }}$ centuries in capitalist economies, class differences in reproductive outcomes were documented using occupational categories as the preferred device for measuring class (Bourdieu and Darbel, 1966; Multiple Authors, 1986; Schneider and Schneider, 1996; Szreter, 1996). The occupation of the male partner in a couple was considered a significant social marker of the couple's social position, primarily because it reflected the man's relationship to the means of production, following traditional Marxian class theory; but also because it captured the confluence of the couple's material conditions of existence, social status, and dispositions towards practices (e.g., modes of living, consumption patterns, and family arrangements).

Class structures have changed substantially since then, as has the sociological understanding of classes (Portes and Canak, 1981; Wright, 2015). Bourdieu has argued that what defines a social class in contemporary societies is a set of historically situated relationships; and that there is no intrinsic value in any social class because there is no essential (social, economic, or demographic) characteristic that can define a social class in a historically meaningful manner (Bourdieu, 1996). This conceptualisation of class has two main strengths. 
First, social class belonging becomes a multidimensional construct. High and sustained levels of economic inequality make social classes more dependent on the intersection of multiple socioeconomic characteristics than on one single feature. Second, explanatory models of family and fertility variation provide an explicit connection between (multidimensional) social classes and mental schemes; i.e., between the material and the symbolic dimensions of social life, respectively (Portes, 2006). Because fertility is affected by factors that pertain to both realms, examining this connection enriches our explanations for between-class variations in fertility outcomes, and for how these patterns have changed over time.

This paper uses these two strengths of this conceptualisation of class to study changes in fertility across the cohorts of women born between 1920 and 1965 in six Latin American countries: Bolivia, Brazil, Chile, Colombia, Mexico, and Paraguay. These six countries had very diverse trajectories of fertility decline and socioeconomic development during the period of study. The selected sample is also advantageous because it includes countries that are located at a wide range of latitudes; that have different population sizes (the three most populous countries of the region, but smaller countries as well); and that, due to data limitations, have been relatively understudied (Bolivia and Paraguay). Moreover, since the mid-1960s, these nations have differed in their approaches to implementing family planning programs (FPPs) (Parrado, 2000; Bongaarts and Sinding, 2009, 2011). Chile, Colombia, and Mexico are known for having successful FPPs that have been strongly supported by national governments. In contrast, the governments of Paraguay, Brazil, and Bolivia have been less successful in providing reproductive and health services to women via FPPs, in part due to considerable resistance in the population (Martine, 1996; Carvalho and Brito, 2005; Miller, 2005). 


\section{Class as a multidimensional and relational construct}

Strongly influenced by the modernisation narrative, individual-level studies of fertility decline in Latin America have focused on fertility differences by socioeconomic markers such as marital status, occupation, educational attainment, and place of residence (Palloni, Hill and Aguirre, 1996; Martinez, 1998; Fussell and Palloni, 2004; Schkolnik and Chackiel, 2004; Adserà and Menendez, 2011; Itaboraí, 2015). However, the statistical categories of these markers cannot be seen as substitutes for social classes.

As modern societies become more complex and unequal, the relevance of configurations of socioeconomic characteristics for social class differentiation increases. The value of a social marker, such as occupational status, depends on the other socioeconomic characteristics of the individual and his/her partner, and the overall distribution of that marker across the population. Moreover, in highly unequal societies, only specific configurations of social markets may exist as demographically significant groups. The primary point is that to account for higher complexity and context-dependency, social classes must be multidimensional and relational. In a multidimensional and relational approach to social class, individuals' socioeconomic conditions matter when they appear jointly, and only in relation to the characteristics of the society as a whole (Emirbayer, 1997; Vandenberghe, 1999).

When I refer to social class as multidimensional, I mean that class membership does not depend on a single characteristic, but rather on the intersection of characteristics (Walby, Armstrong and Strid, 2012; Viveros Vigoya, 2015). When I refer to social class as relational, I mean that the value of a specific configuration of socioeconomic markers depends on the prevalence of that configuration in society. Low-prevalence configurations can be observed among individuals in 
very privileged or very marginalised positions, which in turn determine the societal relations that link these two groups.

For example, having a high school degree is less valuable, and not having a high school degree is more consequential, in urban than in rural areas, because in cities, the vast majority of the population have this level of educational attainment. Likewise, while not owning a dwelling is a clear marker of deprivation in rural areas because having access to land is essential to subsistence in the countryside, not owning a dwelling is generally considered less problematic in urban areas.

The intersection of individuals' socioeconomic living conditions is better able than single categories to capture the context in which couples make decisions about family formation and fertility. Social scientists have broadly documented the correlation between the intersection of socioeconomic conditions and mental dispositions (Johnson-Hanks et al., 2011). Based on this correlation, researchers have incorporated a wide range of non-material factors into their hypotheses related to fertility change (Portes, 2006). These factors, which have been grouped under the category of the symbolic dimension of social life, include social networks, institutional arrangements, norms, beliefs systems (including social stigma), cultural dispositions, and cognitive structures (Caldwell, 1982; Mason, 1997; Johnson-Hanks et al., 2011; Bachrach and Morgan, 2013). Research showing that these factors are imprinted on social agents has led to the development of theoretical concepts such as habitus (Bourdieu, 1996), mental schemes (JohnsonHanks et al., 2011), and segmented rationality (McNicoll, 1980).

While these theoretical frameworks differ to some degree, they all assume that demographic outcomes are the result of the interaction of the material and the symbolic dimensions of social life. Social class belonging is the key concept that links these two realms. 
Geometric Data Analysis (GDA) can be used to operationalise social class as a multidimensional and relational concept. This set of techniques allows researchers to identify the main combinations of socioeconomic markers that distinguish social groups, which are often referred to as probable social classes (Multiple Authors, 2009; Lebaron and Le Roux, 2015).

\section{The concept of probable social class as the link between the material and the symbolic dimensions}

Individuals' social positions are determined by the intersection of their socioeconomic attributes and the characteristics of the society in which they live at a given moment in time. The explanatory power of this theoretical premise relies on the assumption that different material conditions produce segmented rationalities (class-specific habitus, situated mental schemes). Recently developed socio-demographic theories have identified this potential link, along with its connection to broader dynamics of power relationships and social inequality.

"People similar to each other in social and economic positions will tend to be similar in the nature and type of materials available to them [...]. This similarity comes both from the fact that they are likely to perceive and categorize materials in similar ways, as well as from common relations of power and inequality “ (Johnson-Hanks et al., 2011, p. 11).

Different locations in the social space reflect social inequality and power relationships: i.e., some positions are associated with positively valued social characteristics, while others are associated with negatively valued social features (privilege vs. non-privileged positions); and some positions exist (and persist) at the expense of other positions. The permanence over time of these positions, and the distribution of social agents that accompany them, can be called the social structure. A probable social class is a group of people closely located within the social structure. 
Individuals' positions can be derived empirically by applying GDA techniques to individual data on occupation, position at work, housing conditions, educational attainment, access to basic services, and place of residence (material dimension). GDA can be used to identify the main configurations of socioeconomic characteristics that separate (or distinguish) social agents, and to group them into probable social classes. To capture individuals' material living conditions as well as aspects of their social status, the socioeconomic characteristics that are included in the analysis should be as comprehensive as possible. Thus, it may be assumed that class-specific positions in the social space are associated with different representations of the world.

The relative sizes of these classes across generations provide information on how social mobility and class consolidation occur within a given society. It may be assumed that small groups are made up of individuals in hard-to-reach positions, whereas large groups are made up of individuals in common living conditions. If the positions of large groups of socially disadvantaged people (lower classes) remain far from those of small groups of socially advantaged individuals (upper classes) across generations, social mobility is restricted. The growth or stability of societal groups over time reflect class consolidation (Savage et al., 2013; Lebaron and Le Roux, 2015).

Across Latin American societies, social distance implies low levels of interaction between societal groups due to the segregation by social class of residential spaces and educational systems. As socially close people tend to live in close physical proximity to each other, it may be assumed that they have higher levels of social interaction/exchange with each other than with socially distal people. (Davis and Casis, 1946; Portes, 1971, 1989). Moreover, from the primary to the higher education level, there is a clear division between high- and low-class educational institutions (Balan, 2013). Members of the upper classes are more likely to have access to 
competitive (often private) institutions, whereas members of the lower classes are more likely to attend low-quality institutions (Torche, 2014).

Once probable social classes have been identified, class differences in the level and the timing of fertility can be attributed to both their objective positions within the social space (between-class distances), and their associated dispositions (within-class distances). Applying this approach to individuals of successive birth cohorts allows probable social classes to be subject to historical variations. People who were born in the same year have a shared experience of historical time, and are exposed to the same configuration of institutional arrangements (Ryder, 1965, 1983). Combining class and cohort makes it easier to interpret changes in fertility over time; i.e., to understand generational changes in reproductive behaviour, and changes in countries' class structures due to class consolidation.

\section{Data and methods}

The analysis includes native-born women between the ages of 40 and 49 from 21 census samples of six Latin American countries: Bolivia, Brazil, Colombia, Chile, Mexico, and Paraguay. ${ }^{1}$ The countries were selected to represent multiple fertility, developmental, and class structure trajectories (See Figure IA). Only samples with information on the children ever born, the children who survived, and household identification variables are included (Minnesota Population Center, 2015). These three types of variables are used to compute the outcomes of interest: mean children ever born by age 40 (complete fertility rate, CFR), mean age at first birth (MAFB), and mean age at last birth (MALB).

\footnotetext{
${ }^{1}$ Data are publicly available upon registration at: $\underline{\mathrm{https}}$ ///international.ipums.org/international/
} 
Figure I displays the exact years of the 21 censuses used in the analysis (grey vertical lines). As most of these data were collected during the first half of each decade from the 1970s to the 2000s, the women in the samples can be grouped into four birth cohorts: 1920-29 (C1), 1930-39 (C2), 1940-49 (C3), and 1950-65 (C4). Assuming childbearing starts at age 15, the reproductive years of these women span from 1935 to 2005 (period of study).

[Figure I about here]

Women in $\mathrm{C} 1$ and $\mathrm{C} 2$ entered reproductive ages when the socioeconomic transformations associated with fertility decline were still in their early stages (1935 to 1950). In contrast, women in $\mathrm{C} 3$ and $\mathrm{C} 4$ entered reproductive ages when processes of mortality decline, urbanisation, educational expansion, access to modern contraception, and rising female labour force participation were accelerating (1950 to 1980). Additionally, women in C4 can be seen as the "daughters" of women in $\mathrm{C} 1$ and $\mathrm{C} 2$, at least at the population level.

The couple is the unit of analysis because it corresponds to the unit at which fertility decisions are made. Also, to the extent that members of a couple share financial responsibilities, it makes sense to measure social class at this level. There are approximately 1.8 million couples in the analytical sample (Table I).

\section{[Table I about here]}

Having the couple as the unit of analysis requires restricting the sample to women who were living with a spouse or a partner at the time of the census. Thus, the samples used are not representative of all women across the six countries. Specifically, the samples only account for the subset of the women in these populations who survived to ages 40 to 49 , were married or in a 
union, and whose partner/spouse was present at the time of the census. These women represented $62 \%$ of ever-married women and contributed $63 \%$ of total births recorded by the censuses.

I calculate each woman's age at first and last birth by reconstructing her birth history using the ages of her own children who were present in her home (age at birth $=$ age of the woman - age of the own child). As some of the women's children may have been absent and some of births may have been misreported, the mean age at first birth is likely to be overestimated. This upward bias will be more substantial among groups characterised by high infant mortality, early childbearing, early departure from the parental household, and the tendency to misreport the total number of births. These four conditions are more common among socioeconomically disadvantaged couples than among the socially privileged (Fussell and Palloni, 2004). ${ }^{2}$

Consequently, differences in the MAFB by social class are likely to be lower-bound estimates of the actual class differences. While I implement an imputation process to help correct for this bias, the correction is partial because it does not deal with birth misreporting. I do not implement any correction for the MALB, as it is less sensitive to these issues. The last birth is closer in time to the date of data collection, and the youngest child is more likely than the oldest child to be part of the household at the time of the census. When possible, I have computed estimates of the mean age at first and last birth using data from the Demographic and Health Surveys for some of the countries, and have concluded that the results are consistent.

I apply an imputation process similar to the one proposed by Miranda-Ribeiro, Rios-Neto, and De Carvalho (2009). Each incomplete birth history (children ever born > own children at home) is compared with all complete histories (children ever born $=$ own children at home). For each

\footnotetext{
${ }^{2}$ Refer to Tables IA and IIA for additional checks on the representativeness of the analytical sample and the direction of the bias in the MAFB estimates.
} 
comparison, I assign a matching score. This matching score is proportional to the degree of similarity between a pair of birth histories. For example, for a woman who had a total of four children but only two who were living at home at the time of the census, a score of $100 \%$ will be assigned if there is another woman with a complete birth history who had two of her four children at the same ages as the woman with the incomplete birth history. I use this score to identify the most similar birth history for each woman with an incomplete birth history. If an incomplete birth history fully matches more than one complete history, I impute the lowest age at first birth to counterbalance the above-mentioned upward bias. The large sample sizes allow me to apply this procedure separately by country and single-year birth cohort.

Table II presents the number of complete and incomplete birth histories by the women's parity levels. Their matching scores organise incomplete birth histories into five groups ranging from birth histories that do not match at all to birth histories that match almost perfectly (75\% to $100 \%)$. Percentages by row are below the absolute numbers.

\section{[Table II about here]}

Overall, $43 \%$ of the birth histories are complete, $41 \%$ match with a score above $75 \%$, and slightly less than $7 \%$ of the birth histories do not match at all. Birth histories that are complete or are almost perfectly matched together account for $84 \%$ of the total sample. The results displayed in Table II, along with evidence of a negative correlation between socioeconomic status and the prevalence of incomplete birth histories (Table IIA), allow me to interpret class differences in the timing of the first birth as a lower-bound estimate.

I use GDA and clustering techniques to construct country- and cohort-specific social spaces and probable social classes. GDA makes it possible to summarise into factorial dimensions the 
multivariate correlations among a set of variables, called active variables. When active variables refer to couples' socioeconomic conditions and social status, factorial dimensions can be used to compute pair-wise social distance matrices. These matrices can in turn be used to group individuals into probable/multivariate social classes through the application of well-established clustering techniques (Kaufman and Rousseeuw, 1990). When all of the variables are categorical, as is the case here, GDA techniques are called Multiple Correspondence Analysis (MCA) (Le Roux and Rouanet, 2004; Greenacre and Blasius, 2006).

Factorial dimensions have two technical characteristics that make them suitable for use in identifying probable social classes. First, factorial dimensions maximise the proportion of explained variance hierarchically. The first factorial dimension summarises the highest proportion of the variance among active variables like a regression line maximises the $R^{2}$ (conveniently, however, MCA techniques do not require the definition of an outcome variable). This proportion decreases monotonically among the remaining factorial dimensions. When the correlation among variables is strong, a relatively small number of factorial dimensions comprise a large proportion of the total variance. Second, factorial dimensions are orthogonal to one another, which allows me to interpret them as independent factors, and to favour the efficiency clustering algorithms.

Factorial dimensions also have two notable theoretical characteristics. First, they determine the objective (material) position of couples in a given social space while accounting for both microand macro-level characteristics: i.e., the couple-level socioeconomic features and the overall distribution of those features in the population. Second, these data-driven/multidimensional positions are associated with class-specific dispositions and perceptions of the world (symbolic). This assumption holds for this paper because the women in the sample were 40 years and older, 
and the nine active variables measure the current living conditions and the life trajectories of the couple. For example, lacking educational credentials at age 40 signals a life trajectory of restricted access to cultural resources, and lacking an owned dwelling at that age signals limited asset accumulation. While individuals can experience social mobility or improve their socioeconomic conditions after age 40, it may be assumed that after this age, these two aspects of life, like fertility, become increasingly fixed, and generally reflect the overall trajectory of an individual's life.

The nine active variables are educational attainment (the woman's and the partner's), place of residence, ownership of the dwelling, position at work (the woman's and the partner's), economic sector (the partner's), television and electricity, and type of water supply. The variables have been re-coded to avoid categories with relative frequencies below $2 \%$, and to have a similar number of categories across variables. These two features help to ensure that the factorial dimensions are not biased (Lebart, Morineau and Piron, 1997). Couples with similar values along the factorial dimensions are considered socially close. Couples with divergent coordinates are considered socially distal.

For the cluster analysis, between-couple Euclidean distances are computed using the first four factorial dimensions. These social distances are organised in a pair-wise matrix $(D)$. The generic term of this matrix $d_{i j}$ measures the social dissimilarity between couples $i$ and $j$. I apply a combination of hierarchical and non-hierarchical clustering techniques to this matrix to identify probable social classes. The main advantage of using non-hierarchical techniques is that the number of clusters can be determined based on the proportion of explained variance of different cluster solutions. The higher the proportion of explained variance, the better the cluster solution. This proportion is noted $R^{2}(c)$, where $c$ is the number of clusters. Because $R^{2}(c+1)>R^{2}(c)$ for all 
possible values of $c$, an adequate cluster solution can be identified by combining two criteria: the percentage of explained variance by a given partition and the marginal increase in the explained variance between two subsequent partitions. A high value of $R^{2}(c)$ and a small marginal increase between two subsequent cluster solutions $(c$ and $c+1)$ are indicative of an adequate solution. After selecting a number of clusters using these two criteria, I use the k-means algorithm to consolidate the grouping (Pardo and Del Campo, 2007).

\section{Results}

Fertility decline across cohorts was found to be widespread, but unequal, across countries. As Figure II shows, the decrease in the complete fertility rate between the first and last cohort varied between 1.1 children in Bolivia and 2.9 children in Chile. By contrast, the MAFB displayed only small changes. The MALB declined substantially—by at least three years—between the first and the last cohort, except in Bolivia. ${ }^{3}$

\section{[Figure II about here]}

High levels of income, land tenure, and wealth inequality are characteristic of the robust stratification systems in Latin American (Portes, 1985; Morley, 2001; Portes and Hoffman, 2003; Williamson, 2010). These social and economic inequalities have two key features. First, there is a pronounced and self-perpetuating concentration of resources among the upper classes, most of whom live in capital cities. Second, the role of educational attainment in reducing inequality and facilitating social mobility is small (Hoffman and Centeno, 2003; Torche, 2014). Consequently, most of the changes in the class structure of Latin American societies during this period resulted

\footnotetext{
${ }^{3}$ Estimates from the Demographic and Health Surveys for the three indicators display consistency in the cohort trends when compared to the census samples.
} 
in the enlargement of the lower classes. It has, for example, been observed that for the rural poor and for rural-to-urban migrants, the expected societal benefits of urbanisation, access to contraception, higher educational attainment, and female labour force participation have produced little, if any, actual return (García and de Oliveira, 2011). The socioeconomic profiles of the studied cohorts reflect these societal changes.

Table III shows the socioeconomic profiles of couples of the first and the last cohorts studied. In all six countries, the proportions of men and women with no education declined over time to levels below $60 \%$. The shares of the population with primary education grew for both sexes, but having a university degree remained uncommon. Despite educational improvements, more than $50 \%$ of the individuals of the last cohort had no more than a primary-level education.

\section{[Table III about here]}

The effects of urbanisation and improvements in living conditions clearly differentiate these two cohorts. More than half of the couples in the last cohort were living in an urban area; owned a dwelling; and had access to electricity, a television, and piped water (exclusive or shared). However, the potential societal benefits associated with urbanisation did not materialise for the entire population, in part because cities did not have the level of industrialisation that would enable rural migrants to find jobs that offer upward mobility. Moreover, these migrant populations lacked the training to enter highly skilled occupations or to develop new businesses (Portes, 1989). In addition, studies on Latin American economic development have suggested that the decrease in agricultural production associated with migration to urban areas was not beneficial, as these countries started to import food that could have been produced internally (García-Nossa, 1980, 1981; Escobar, 2007). The distribution of the labour force by sectors across cohorts reveals the extent of these changes (last rows in Table III). 
Across the studied cohorts, the share of men occupied in agriculture decreased, whereas the shared of men employed in the service industry went up. These changes reflect the general shift in these national economies towards the tertiary sector as their plans for industrialisation largely failed and their efforts to implement the import-substitutions model were unsuccessful (Baer, 1972; Bethell, 1998). While the share of workers in manufacturing grew in Bolivia and Brazil, it declined in the other four countries. The construction sector grew in all six countries, along with the sales and the public administration and education sectors. The last category employed the smallest share of the labour force overtime in all of the studied countries. Female labour force participation rose in all six countries, but more than half of the women in the last cohort reported being out of the labour market at the time of the census.

Across these cohorts, positively and negatively valued individual-level social markers were strongly correlated. At the aggregate level, these correlations consolidated sharply unequal social classes. It was not until after the 1990s that increasing inequality trends underwent some reversals. The high proportion of variance accounted for by the first factorial dimensions of the MCAs reflects these enduring correlations. Figure III displays these proportions for the first eight factorial dimensions in each of the 21 MCAs. There is one panel per country, and the proportion for the first dimension is written as a label to facilitate visualisation.

[Figure III about here]

The figure shows that for all birth cohorts, the first two factorial dimensions accounted for more than $75 \%$ of the total variance of the active variables (min: $78 \%$ for $1940-49$ Chile, max: $82 \%$ for 1920-29 Bolivia). This concentration of explained variance suggests that Latin American social spaces are rigidly structured, as the couples' socioeconomic and social status characteristics were strongly correlated. The variables that contributed the most to the first factorial dimension were 
those associated with the availability of economic resources: namely, place of residence, access to basic services (electricity, television, and water supply), and occupation. The variables with the largest contributions to the second dimension were the educational attainment of women and their partners (cultural resources). These differential contributions mean that there were two main "independent" factors that were shaping the social structure within each country: namely, economic and cultural resources. However, the distinction between these two types of resources requires a caveat. In Latin American societies, there is no social class with low economic capital and high cultural capital. While keeping this in mind and for the sake of conciseness, I will refer to the first dimension as an indicator of economic capital and the second dimension as an indicator of cultural capital.

The proportion of retained variance in the first dimension declined across cohorts, whereas that in the second dimension increased. This means that over time, cultural resources played a greater role than economic conditions in differentiating the social classes. The proportion of explained variance in the first dimension was above 0.8 in all six countries for the first cohort, but varied between 0.68 in Chile and 0.85 in Bolivia for the last cohort. These changes reflect two aspects of societal transformation: first, an increase in the relative importance of cultural resources in structuring social spaces; and, second, a higher level of heterogeneity across cohorts in couples' socioeconomic conditions, and especially in their educational attainment levels. Full representations of the MCA outputs, including the distributions of variables and couples along the first two factorial dimensions, are available in Figures IIA to VIIA.

The cluster analysis provided further confirmation of the dual dynamics of improving socioeconomic conditions and the endurance of social stratification. Three main results applied to all six countries. First, the number of social classes was very stable. Second, the relative sizes of 
the classes and their variations over time (class consolidation) were similar. Third, the social distances between classes were substantial, and persisted across cohorts. Figure IV presents the proportion of explained variance $\left(R^{2}(c)\right)$ by several numbers of clusters by country and cohort.

[Figure IV about here]

In all cases, five clusters (dotted vertical line) accounted for at least $55 \%$ of the total variance of the social distances among couples. The marginal increase in this percentage between clusters 5 and 6 was small (less than seven percentage points). The consistency of these results across the studied countries and cohorts suggests that these Latin American societies remained stratified over time across a relatively stable number of groups. I have labelled these classes using terms that refer to positions in space: Lowest, Low, Lower-middle, Upper-middle, and Upper. Given the overlapping nature of these classes, I have chosen to use the expression "low classes" (with a lower-case ' 1 ') to refer to the Lowest, Low, and Lower-middle classes; the expression "middle classes" (lower-case 'm') to refer to the Lower-middle and Upper-middle classes, and the expression "upper classes" (lower-case 'u') to refer to the Upper-middle and Upper classes.

As Table IV shows, the countries' class composition varied widely over time among the lower classes, which signals that class consolidation mainly occurred among the lower layers of the stratification system. Between the first and the last cohort, the proportion of couples in the Lowest class diminished in all six countries, and especially in the three countries with relatively high levels of development (46\% to $11 \%$ in Brazil, $24 \%$ to $11 \%$ in Chile, and $37 \%$ to $7 \%$ in Mexico). In the last cohort, the share of couples in the Low class was above $20 \%$ in all six countries except Colombia (13\%). The share of couples in the Lower-middle class increased across cohorts, and accounted for at least $20 \%$ of couples in the last cohort (min: $19.6 \%$ in Chile, 
max: $32.5 \%$ in Mexico). In all six countries, the share of couples in the Low class comprised at least $62 \%$ of the total.

[Table IV about here]

The shares of couples in the Upper-middle classes were smaller and less variable in terms of size. Across cohorts, they tended to either increase or remain stable at relatively low levels (min: 13.7\% in Bolivia, max: $23.1 \%$ in Chile). The proportions of couples in the Upper class varied less across countries in the first cohort, and increased over time. In all six countries, the Upper class was small; comprising less than $6 \%$ of the couples in the first cohort and $16 \%$ of the couples in the last cohort.

Figure $\mathrm{V}$ displays the mean location of each class cohort according to the first two factorial dimensions of the MCAs. Since the MCAs are country- and cohort-specific, only the distances among social classes in the same cohort can be interpreted (dotted lines). This plane constitutes the best possible two-dimensional representation of Latin American social spaces as operationalised here. The sizes of the points are proportional to the within-cohort percentage of couples (as in Table IV). The background lines are separated by one standard deviation to indicate the statistical significance and substantial importance of the differential positions of the classes.

[Figure $\mathrm{V}$ about here]

In the figure, the five probable social classes form a J-shaped curve. The upper-left part of the social space is empty because Latin American societies do not have a social class with low economic capital and high cultural capital. I have added the CFR for the first (underlined number) and the last cohort to jointly show the processes of class consolidation and fertility 
decline. Significant and sustained differences across the CFR of distal classes reflect the divergent contexts in which couples make decisions regarding fertility. The similarity in the CFR of socially close classes reflects the reverse.

From left to right, the first class that appears is the Lowest (red). This group is composed of couples with no education who were engaged in primary activities as self-employed workers in rural areas. This class also had the lowest levels of access to basic services (electricity, TV, piped water), although their homeownership rate was not the lowest across classes. Among the last cohort, the CFR for this group was above 4.7 in all six countries, except in Chile. In general, heterogeneity in the CFR of this class across countries increased over time. The CFR of women in the Lowest class was between 6.9 in Bolivia and 8.3 in Colombia for the first cohort, but was between 3.5 in Chile and 7.2 in Bolivia for the last cohort.

The right side of the social space shows urban couples. This population is divided into four classes: Low (orange), Lower-middle (green), Upper-middle (blue), and Upper class (purple). The positioning of the Low class below the Lowest class on the vertical axis does not mean that the couples in the latter group had lower levels of cultural capital. This apparent difference is just a consequence of presenting the social space in a two-dimensional way.

The couples in the Low class (orange) had either no education or primary education only. They tended to work in construction and manufacturing. In terms of their place of residence, the couples in this class were predominantly living in urban areas; but in countries like Bolivia, Colombia, and Mexico, some couples in the Low class were living in rural areas. Their CFR was above six in all countries for the first cohort, and it decreased to between 3.1 in Chile to 6.0 in Bolivia for the last cohort. Given the relative size of the Lowest and Low classes combined, most of the change in aggregate fertility came from the changes in these two groups. 
Most of the couples in the Lower-middle class had primary education, and were working in unskilled service, construction, or manufacturing jobs. The couples in this class had the lowest rates of homeownership. Their fertility started at levels between 4.6 in Brazil and 6.7 in Colombia in the first cohort, and then declined to levels below 4.0 in all countries except Bolivia. Along with their counterparts in the Low class, the couples in the Lower-middle class were likely to be domestic migrants who moved from rural areas to intermediate/small cities searching for better working conditions in response to the weakening of agricultural production (Jelin, 1977; Palloni, Hill and Aguirre, 1996). Census data do not allow me to track these moves, but the literature describing the urbanisation process in Latin America suggests that people who migrated from rural to urban areas joined these classes (Ducoff et al., 1965; Portes, 1989; Rodríguez Vignoli, 2004; Delgado-Wise, 2014). Migrants to Santiago de Chile may be a slight exception to this pattern, as according to Balan (1969), migrants in the city of Santiago had better socioeconomic conditions than non-migrants.

Most of the couples in the Upper-middle class had secondary education, and some had university degrees. They were associated with non-manual occupations, and were mostly living in urban areas. Compared to the previous three groups, the couples in this class had significantly higher levels of access to basic services and cultural resources. Access to water and electricity was nearly universal among the couples in this class, and a large proportion of them had completed secondary education. Their CFR was between that of the couples in the Lower-middle and the Upper classes. In Brazil, Colombia, and Chile, the CFR of this group decreased substantially across cohorts, converging to levels of around 2.5 children per woman. For the other three countries, the lowest observed CFR ranged from 3.1 in Paraguay to 3.8 Bolivia. 
Most of the couples in the Upper class had high educational levels, were living in a capital city, and had non-manual jobs in the service, education, or public administration sectors. As they were primarily wage/salary employees or employers, they had relatively high levels of social status, economic resources, and cultural capital. Unlike the lower classes, this group was relatively homogeneous in terms of size and CFR across the six countries, especially among the last cohort. The CFR for the couples in this class ranged from 2.1 in Brazil to 2.9 in Bolivia and Paraguay. Thus, the Upper class could be characterised as a small, low-fertility class that displayed substantial levels of convergence across the six countries over time.

The relative sizes of and the persistent distances among the probable social classes reflect the dynamics of class consolidation. Smaller classes are more tightly enclosed than larger classes. Given the combination of the varying socioeconomic conditions in each class and the social distances among them, moving between distal classes across generations is more difficult (less likely) than moving across classes that are in closer proximity. It is unlikely that the small increases observed in the upper classes across cohorts were driven by the incorporation of men and women born to couples in the Lowest or Low classes. These two groups were separated from the upper classes by more than two standard deviations in both directions, which means that their children were born in very distinct geographical areas, and grew up in substantially disadvantaged opportunity structures in terms of access to economic and cultural resources. Couples in the Lowest and Low classes were separated from Upper-class couples by, on average, at least 3.4 and 2.5 standard deviations, respectively (Refer to Table IIIA for the full list of between- and within-class mean distances).

To summarise, the CFR was closely associated with locations in the J-shaped social space. Despite the decline in fertility, this relationship lasted over time. For the couples of the first birth 
cohort, large families (seven to eight children) are displayed on the left side of the social space, whereas medium and small families (three to six) are shown on the right. The distribution of children ever born among couples on the right side tracks the volume of cultural capital (bottom to top, large to small families). Differences along this dimension are smaller than those of the first dimension.

A similar association can be seen for couples in the last cohort: i.e., large families are displayed on the left-hand side of the social spaces, and small families are shown on the right side. However, differences along the second dimension are larger among couples of the last cohort than among couples of the first cohort given the increased relevance of cultural resources in differentiating social classes and shaping fertility outcomes. On the right side of the plots, the CFR ranges from six among the low classes to two among the upper classes.

Table V illustrates the class differences in the timing of childbearing by class and cohort. Despite some exceptions, the variation patterns are similar across the six nations. As a robustness check, Table IVA displays the distribution of women by parity levels, including women without children. Class variations in parity distribution are consistent with the following interpretations.

\section{[Table V about here]}

The MAFB displays three interrelated patterns: (1) a positive association with class, (2) increasing between-class heterogeneity across cohorts, and (3) divergence over time among probable social classes. Women in the upper classes tended to have their first child later than women in the other classes. Because the MAFB declined for couples in the lower classes and increased or remained high for couples in the upper classes, cross-class differences in the age at first birth were more significant in the last cohort than in the first cohort. The MALB correlated 
negatively with social class. Across cohorts, this correlation weakened due to sharp declines in the MALB among couples in the lower classes.

These patterns of changes in fertility timing suggest that social changes had a differential association with the fertility outcomes of each social class. This result is consistent with the idea of fertility as a reproduction strategy closely linked to the sources and conversion rates of capitals (Torrado, 1981; Bourdieu, 1994). Education became more valuable over time as the national economies required better-trained workers living in large cities. The potential effects of such changes on the timing of childbearing were more likely to operate among the couples in the upper classes. These couples were the ones who had the greatest need to convert their economic capital into cultural through formal education; i.e., to spend more time in the educational system before having children. Meanwhile, the diversification of the labour market in the cities opened up new employment opportunities for men and women from the Lower-middle class (some of whom migrated from rural areas), but these new positions did not require tertiary education. Lowermiddle-class women were joining the labour force both formally and informally; potentially in response to their family's financial needs. This shift may have contributed to the decline in fertility (Schkolnik and Chackiel, 2004; Adserà and Menendez, 2011). On the other side of the social spectrum, among couples in the Lowest and Low classes, sources of capital continued to be scarce (due to the lack of basic services and limited access to education) and less valuable (due to economic shifts favouring the tertiary sector), which led them to have fewer children and to stop childbearing earlier.

These divergent trends in complete fertility and the timing of childbearing also suggest that access to modern contraception and FPPs varied across social classes. The women in the Lowest and Low classes experienced substantial declines in the CFR, an acceleration in the transition to 
parenthood, and a sharp decline in the age at last birth. These changes may be attributable to sterilisation and a lack of access to FPPs, which are common in rural areas (Bronfman, López and Tuirán, 1986; Caetano and Potter, 2004). By contrast, couples in the upper classes delayed the transition to parenthood and shortened their childbearing period by maintaining a stable age at last birth. This sustained delay in the transition to childbearing is likely attributable to the use of contraceptive methods other than sterilisation, as has been observed among socially privileged groups across different historical contexts (Knodel and Van de Walle, 1979).

It is clear that predictions from the quality-quantity trade-off hypothesis-which states that fertility declines because women prefer to have fewer children so they can invest more resources in them-can apply to upper-class couples. Upper-class couples have both the dispositions and the resources to opt for a family size that maximises their investment in childrearing. Such predictions seem untenable for the rest of the social spectrum; as couples in the lower classes had minimal access to economic and cultural resources, it seems doubtful that they were seeking to maximise the transmission of intergenerational resources. The rationale for fertility decline among the lower classes was more likely related to the financial constraints that macro-economic changes imposed on their lives than to a rational calculation of ends and means in order to maximise their offspring's well-being.

Similarly, the opportunity cost hypothesis—which argues that women choose joining the labour force over childbearing — is plausible among upper-class women only. It is more likely that both a higher opportunity cost for entering the labour market, as well as the disposition to identify such a cost (rational calculation) and to delay the first birth in response, were present in educated women living in urban areas, but not in uneducated women (Low and Lower-middle classes) living in the countryside (Lowest class). According to the data presented here, only upper-class 
women delayed the first birth; whereas women from lower classes accelerated this transition over time. Van de Kaa (1996) have already pointed to this mismatch when discussing demandoriented explanations of fertility decline:

"Important findings appear to be that there is a strong interaction between [the] quantity and quality of children although they are not close substitutes [...]. The central problem of the narrative, however, is that it cannot be anchored firmly in what we know about the way things happen in this world. While one might, with some imagination, place the story in the context of middle-class America, it is difficult to see how it could apply in a less developed country where time is abundant and 'consumer choice' largely absent." (van de Kaa, 1996, p. 410)

Finally, the similarities in the fertility outcomes among the socially close classes and the differences in the fertility outcomes among the socially distal classes suggest that any diffusion of social norms regarding the timing of family formation and family size is more likely to occur within than between classes, or, at most, between socially close classes. The social distance between the lower and the upper classes (on average, at least 1.7 standard deviations) and the fact that they tend to live in geographically different places (rural areas, urban areas, and large cities) imply that social interaction and social contagion/imitation across these classes are very unlikely.

\section{Conclusions and discussion}

As a result of dramatic socioeconomic changes in Latin America, the cohorts born in these countries between 1920 and 1965 faced very different family formation contexts. An underdeveloped region was transformed into a developing region through the implementation of farreaching and long-lasting social and economic reforms that exacerbated social inequalities. Fertility decline was a component of this transformation, and followed class-specific trajectories 
that contributed to the consolidation of highly unequal social stratification systems. I used a multidimensional and relational definition of social class to describe these processes and to reinterpret some of the classical theories of fertility change. With this approach to social classalong with a theoretical assumption regarding class-specific dispositions-I was able to identify three main aspects of the relationship between fertility and class: (a) the enduring connection between social stratification and fertility, (b) the co-existence of diverse fertility decline trajectories, and (c) the dual role of social distances in promoting and preventing ideational change.

This paper showed that the complete fertility levels across all of the cohorts in the six Latin American countries included in the study were closely tied to the overall distribution of social classes within the social space. Over time, unequal socioeconomic development across countries led to an unequal-yet generalised—fertility decline, which was accompanied by changes in the countries' class compositions. Class consolidation consisted primarily of the growth of the Low and Lower-middle classes, the two groups with the most significant changes in the CFR and the MALB. These two groups were, consequently, found to be the main contributors to fertility decline.

The results clearly showed that the lower- and upper-class couples experienced divergent fertility transitions. While the upper-class women delayed the first birth, kept the childbearing period relatively stable, and experienced the smallest CFR declines; the lower-class women accelerated the first birth, shortened the childbearing period, and reduced their complete fertility. Middleclass couples deserve their label not only because of their socioeconomic attributes, but because the characteristics of their fertility transition were between those of the lower- and upper-class couples. The lower a couple's class, the more likely the female partner was to follow a stopping 
strategy to reduce the number of children, potentially through sterilisation. Class differences in access to (voluntary or forced) sterilisation may partly explain this trend, because this practice is highly effective for stopping childbearing, and its use was more prevalent among women of lower than of higher socioeconomic status. At the other end of the class spectrum, the higher a couple's class, the more likely the female partner was to delay the first birth and achieve a relatively small family size by age 40 . This fertility trajectory tends to be associated with contraceptive methods other than early sterilisation.

The class-specific trajectories observed here call into question the predictions of classical theories of fertility decline that have focused on interpreting independent (pure) associations (effects) of socioeconomic variables on fertility. Because social classes are multidimensionally-constructed, socioeconomic changes have class-specific associations with fertility and fertility timing. These class-specific relationships are only evident if the focus is on the intersection of individuals' material conditions of existence (their class) and the class dispositions they generate. To further illustrate this point, let us consider changes in educational attainment, female labour force participation, and access to modern contraception-three of the most studied factors associated with fertility decline.

Educational attainment did not grow substantially for the lower classes, yet these three groups experienced significant declines in the number of children ever born. Given the sizes of these social classes, their contributions to the overall fertility decline were the largest; which suggests that education did not play a central role in the overall changes in fertility levels at the country level. The contrary pattern was observed for upper-class couples: the proportions of these couples with secondary and tertiary education increased substantially across cohorts, which undoubtedly contributed to their lower fertility and delayed transitions to parenthood. Their contribution to the 
overall fertility decline was small, given their reduced size as a class. It is important to recall that there was a spatial factor in these classes, as the couples in the lower classes were mostly living in rural areas, whereas the Upper-middle- and Upper-class couples were mostly living in urban areas and capital cities, respectively. These spatial differences explain not only the differences in the couples' opportunity structures to access formal education and non-manual (clerical) jobs, but the differential returns they had from gaining educational credentials vs. entering parenthood.

The finding that women in the lower and middle classes had similar labour force participation rates but very different fertility levels suggests that the association between these two variables was class-specific. The conflict between childrearing and labour force participation was likely to be more acute in urban areas, especially among recently arrived migrant couples from rural areas. In cities, daily commutes to work are necessary; whereas in rural areas, the household and the place of work are more likely to coincide (Hervitz, 1985; Schockaert, 2005). Moreover, multigenerational households are more prevalent in rural than in urban areas, which suggests that kinship support for childbearing and childrearing may favour the coexistence of relatively high fertility and labour force participation (De Vos, 1995; Bongaarts, 2001).

Modern contraceptive methods were not available to the women of the first two birth cohorts. However, among the subsequent cohorts, upper-class women had lower completed fertility and later transitions to motherhood than women in other classes. A persistent disposition towards having a smaller family, along with the material means to practice birth control effectively (without modern contraception), may explain the similarities in the fertility outcomes of the upper-class couples across the six countries. At the other end of the class spectrum, even among the last cohort in countries with strong FPPs, lower-class couples did not display fertility outcomes that are consistent with the use of contraceptive methods such as condoms, the pill, or 
the intrauterine contraceptive device (IUD). There are two potential explanations for this result. First, because the lower classes were less likely to have access to these methods because they were living in remote rural areas with less access to basic services, it is unlikely that the fertility decline observed among lower-class couples is attributable to health-related services. See the work of Caetano and Potter (2004) for Northeast Brazil, Svallfors and Billingsley (2019) for Colombia, and Brofman, López, and Tuirán (1986) for Mexico, and Vidal-Zeballos (1994) for Bolivia. Second, the disposition of lower-class couples to incorporate the use of modern contraception into their reproductive lives may differ from that of the upper classes. Studies on teenage childbearing in Colombia have shown that low-SES teenagers report negative attitudes towards the use of condoms, as it can raise issues of trust with their partners (Flórez and Soto, 2007). Studies conducted elsewhere have also shown that modern contraception can be used not only to limit fertility, but to control birth spacing in contexts with rigid social norms on these issues (Bledsoe et al., 1994).

The role of ideational change and social contagion is also subject to class-specific conditions. La Ferrara, Chong, and Duryea (2012) used the 1991 Brazilian census and spatial information on the expansion of the largest Brazilian television network during the early 1980s to explore the role of ideational change on fertility decline. The authors reported an overall negative causal effect of television on fertility. They attributed this effect to the fact that Brazilian soap operas display small families (two children) as an ideal model for acquiring social mobility. However, according to the evidence presented here, it is more likely that this effect operated on middle- and upperclass couples than on couples in the lowest classes given the lack of access of the latter to electricity service and television. Indeed, it should be noted that among the couples in the upper classes, the most common parity level was two children after the second cohort a cohort who did not benefit from the expansion of television. Ideational change towards a preference for smaller 
families is more likely to operate among people with both (1) access to sources promoting these types of families (television), and (2) the socioeconomic motivation to incorporate such changes.

Ideational change towards a preference for smaller families can also spread across social groups through social interaction. Studies on fertility transitions in Europe and in Latin America have argued that over time, fertility outcomes converge across classes as upper-class behaviour spreads to the lower classes (Schmertmann, Potter and Cavenaghi, 2005; Dribe et al., 2017). The evidence presented here contradicts this hypothesis. The durability of the distance across classes in the social space, the degree of residential segregation by class (rural vs. urban, but also within cities between centric and peripheral neighbourhoods: villas miseria, barrios, barrios de invasion, favelas), and the similarities of fertility outcomes within classes that we observed suggest that social contagion is more likely to occur within than between classes. In Latin America, the concentration of resources in large cities and the residential segregation that characterises urban development make within-class interactions more likely to occur, and increase the chances that these interactions will be more instrumental in transmitting ideas than between-class interactions. Moreover, the historical isolation of rural areas, especially those affected by violence, reduce the chances of between-class interactions taking place (Castro Torres and Urdinola, 2019).

Consequently, it is unlikely that the fertility decline among lower-class couples was driven by their intentions to replicate the fertility behaviour of upper-class women. Indeed, these patterns of decline do not look similar. Analogously, the strong similarities observed in the fertility outcomes of the middle classes (Lower-middle and Upper-middle) implies that their physical proximity (urban areas) as well as their social proximity may have played a role in making them demographically similar. The so-called leaders/forerunners of demographic change and their 
corresponding social imitators may exist, but primarily within each class; or, at most, between socially close classes.

All in all, these analyses suggest that classical explanations of fertility decline must be used in conjunction with a multidimensional and relational definition of social class. Otherwise, such explanations fall short in accounting for demographic changes, especially among couples in the Lowest, Low, and Lower-middle classes, who are the most critical contributors to fertility decline and class consolidation.

By letting the social space be contingent on the historical context and by putting the relative position of collectives in the social space as an explanatory category, both micro- and macrolevel factors are inductively incorporated in our understanding of societal change. Because it focuses on the historical experiences of cohorts and of probable social classes, rather than on the correlation (or pure causal effect) between dependent and (rarely) independent variables, this approach forces the accounts to be about the actual makers of demographic and societal change (Emirbayer, 1997; Lieberson and Horwich, 2008). This distinction is not minor, as it implies the construction of scientific narratives in which the subjects of the statements are not variables; e.g., education does $X$, unemployment prevents $Y$, migration causes $Z$, but social groups defined in terms of birth cohorts, and classes.

The limitations of this work underline lingering questions. First, there is a dearth of qualitative work on fertility preferences and intentions_-and the realisation thereof_-in Latin America. This type of work can shed light on how class conditions relate to fertility outcomes, and assess the extent to which quantitative approaches capture these relations correctly. Second, more detailed datasets such as those of the Demographic and Health Surveys or country-specific fertility surveys can be used to examine the influence of domestic and international migration on fertility. 
These two demographic dynamics were pervasive after 1950-60, and both are very likely to affect family dynamics (Landale and Oropesa, 2007). 


\section{References}

Adserà, A. and Menendez, A. (2011) 'Fertility changes in Latin America in periods of economic uncertainty', Population Studies, 65(1), pp. 37-56. doi: 10.1080/00324728.2010.530291.

Babbie, E. (2011) The Basics of Social Research. Belmont, CA: Wadsworth.

Bachrach, S. and Morgan (2013) 'A Cognitive - Social Model of Fertility Intentions', Population and Development Review, 39(3), pp. 459-485.

Baer, W. (1972) 'Import Substitution and Industrialization in Latin America : Experiences and Interpretations', Latin American Research Review, 7(1), pp. 95-122.

Balan, J. (1969) 'Migrant-Native Socioeconomic Differences in Latin American Cities: A Structural Analysis', Latin American Research Review, 4(1), pp. 3-29.

Balan, J. (2013) 'Introduction - Latin American Higher Education Systems in a Historical and Comparative Perspective', in Latin America's New Knowledge Economy. 1st edn. Sewickley, PA: IIEBooks Fulfillment Center, pp. vii-xx.

Becker, G. (1981) A Treatise on the Family. Cambridge, MA: Harvard University Press.

Bethell, L. (1998) 'Latin America: Economy and Society Since 1930', in The Cambridge History of Latin America. 1st edn. Oxford: Oxford University Press. doi:

10.1017/CBO9781107415324.004.

Bledsoe, C. H. et al. (1994) 'Constructing Natural Fertility : The Use of Western Contraceptive Technologies in Rural Gambia', Population and Development Review, 20(1), pp. 81-113. Available at: http://www.jstor.org/stable/2137631.

Bongaarts, J. (2001) 'Household Size and Composition in the Developing World in the 1990s', Population Studies, 55(3), pp. 263-279.

Bongaarts, J. (2003) 'Completing the Fertility Transition in the Developing World : The role the of fertility transition preferences in differences', Population Studies, 57(3), pp. 321-335.

Bongaarts, J., Mensch, B. S. and Blanc, A. K. (2017) 'Trends in the age at reproductive transitions in the developing world: The role of education', Population Studies. Taylor \& Francis, 71(2), pp. 139-154. doi: 10.1080/00324728.2017.1291986.

Bongaarts, J. and Sinding, S. (2011) 'Population Policy in Transition in the Developing World', Science, 333(6042), pp. 574-576. doi: 10.1126/science.1207558.

Bongaarts, J. and Sinding, S. W. (2009) 'A response to critics of family planning programs', 39(1).

Bongaarts, J. and Watkins, S. (1996) 'Social Interactions and Contemporary Fertility Transitions', Population and Development Review, 22(4), pp. 639-682. doi: 10.2307/2137804. 
Bourdieu, P. (1994) 'Stratégies de reproduction et modes de domination', Actes de la recherche en sciences sociales, 105(1), pp. 3-12. doi: 10.3406/arss.1994.3118.

Bourdieu, P. (1996) Distinction. A Social Critique of the Judgement of Taste. 8th edn. Cambridge, MA: Harvard University Press.

Bourdieu, P. (2000) Pascalian Meditations. 1st edn. Stanford University Press.

Bourdieu, P. (2005) The Social Structures of the Economy. 1st edn. Cambridge, UK: Polity Press.

Bourdieu, P. and Darbel, A. (1966) 'La fin d'un malthusianisme', in Le partage des bénéfices. Paris: Editions de Minuit.

Bronfman, M., López, E. and Tuirán, R. (1986) 'Práctica anticonceptiva y clases sociales en México : la experiencia reciente', Estudios Demográficos y Urbanos, 2(2), pp. 165-203.

Caetano, A. J. and Potter, J. E. (2004) 'Politics and Female Sterilization in Northeast Brazil', Population and Development Review, 30(1), pp. 79-108.

Caldwell, J. (1982) Theory of Fertility Decline. London: Academic Press.

Carvalho, J. A. M. De and Brito, F. (2005) 'A demografia brasileira e o declínio da fecundidade no Brasil: contribuições, equívocos e silêncios', Revista Brasileira de Estudos de População, 22(2), pp. 351-369. doi: 10.1590/S0102-30982005000200011.

Castro Martin, T. and Juarez, F. (1995) ‘The Impact of Women's Education on Fertility In Latin America: Searching for Explanations', International Family Planning Perspectives, 21(2), p. 52. doi: $10.2307 / 2133523$.

Castro Torres, A. F. and Urdinola, B. P. (2019) 'Armed Conflict and Fertility in Colombia, 20002010', Population Research and Policy Review, 38(2), pp. 173-213. doi: 10.1007/s11113-0189489-x.

Cleland, J. and Wilson, C. (1987) 'Demand Theories of the Fertility Transition : an Iconoclastic View', Population Studies, 41(1), pp. 5-30.

Davis, K. and Casis, A. (1946) 'Urbanization in Latin America', The Milbank Memorial Fund Quarterly, 24(2), pp. 186-207.

Delgado-Wise, R. (2014) 'A Critical Overview of Migration and Development: The Latin American Challenge', Annual Review of Sociology, 40. doi: 10.1146/annurev-soc-071811145459 .

Dribe, M. et al. (2017) 'Socio-economic status and fertility decline: Insights from historical transitions in Europe and North America', Population Studies. Taylor \& Francis, 71(1), pp. 3-21. doi: 10.1080/00324728.2016.1253857.

Ducoff, L. et al. (1965) 'The Role of Migration in the Demographic Development of Latin America', The Milbank Memorial Fund Quarterly, 43(4), pp. 197-216. 
Emirbayer, M. (1997) 'Manifesto for a Relational Sociology', American Journal of Sociology, 103(2), pp. 281-317. doi: 10.1086/231209.

England, P. and Budig, M. J. (1998) 'Gary Becker on the Family: His Genius, Impact, and Blind Spots', in Clawson, D. (ed.) Required Reading: Sociology's Most Influential Books. Amherst: University of Massachusetts Press, pp. 95-111.

Escobar, A. (2007) La Invención del Tercer Mundo. Construcción y deconstrucción del desarrollo. 1st edn. Caracas, Venezuela: Fundación Editorial el perro y la rana.

La Ferrara, E., Chong, A. and Duryea, S. (2012) 'Soap operas and fertility: Evidence from Brazil’, American Economic Journal: Applied Economics, 4(4), pp. 1-31. doi: 10.1257/app.4.4.1.

Flórez, C. and Soto, V. (2007) 'Fecundidad adolescente y desigualdad en Colombia', Notas de Población - CEPAL, 83(1), pp. 41-74.

Fussell, E. and Palloni, A. (2004) 'Persistent Marriage Regimes in Changing Times', Journal of Marriage and Family, 66(5), pp. 1201-1213.

García-Nossa, A. (1980) Reforma Agraria y Desarrollo Capitalista. 1st edn. Mexico D.F.: Universidad Autónoma de México.

García-Nossa, A. (1981) Desarrollo agrario en América Latina. Mexico D.F.: Fondo de Cultura Económica.

García, B. and de Oliveira, O. (2011) 'Family Changes and Public Policies in Latin America', Annual Review of Sociology, 37(1), pp. 593-611. doi: 10.1146/annurev-soc-081309-150205.

Greenacre, M. and Blasius, J. (2006) Multiple Correspondence Analysis and Related Methods. 1st edn. Chapman \& Hall/CRC Press.

Guzmán, J. (1996) The fertility transition in Latin America. New York: Oxford Universit Press.

Guzmán, J. et al. (2006) 'The Demography of Latin America and the Caribbean since 1950', Population-E, 61(5-6), pp. 519-576. doi: 10.3917/pope.605.0519.

Hervitz, H. M. (1985) 'Selectivity, Adaptation, or Disruption? A Comparison of Alternative Hypotheses on the Effects of Migration on Fertility: the Case of Brazil.', The International migration review, 19(2), pp. 293-317. doi: 10.2307/2545774.

Hirschman, C. (1994) 'Why fertility changes', Annual Review of Sociology, 20, pp. 203-233.

Hoffman, K. and Centeno, M. A. (2003) 'The Lopsided Continent: Inequality in Latin America', Annual Review of Sociology, 29. doi: 10.1146/annurev.soc.29.010202.100141.

Itaboraí, N. R. (2015) 'Las desigualdades de clase en el comportamiento reproductivo en el Brasil: democratización incompleta y paradojas de la fecundidad juvenil', Notas de Población CEPAL, (100), pp. 61-90. 
Jelin, E. (1977) 'Migration and Labor Force Participation of Latin American Women: The Domestic Servants in the Cities', Signs, 3(1), pp. 129-141. doi: 10.1086/493446.

Johnson-Hanks, J. et al. (2011) Understanding Family Change and Variation: Toward a Theory of Conjunctural Action. 1st edn. New York: Springer.

Juarez, F. and Gayet, C. (2014) 'Transitions to Adulthood in Developing Countries', Annual Review of Sociology, 40, pp. 521-538. doi: 10.1146/annurev-soc-052914-085540.

van de Kaa, D. J. (1996) 'Anchored Narratives : The Story and Findings of Half a Century of Research into the Determinants of Fertility', Population Studies, 50(3), pp. 389-432.

Kaufman, L. and Rousseeuw, P. J. (1990) Finding Groups in Data: An Introduction to Cluster Analysis. New York: Wiley.

Knodel, J. and Van de Walle, E. (1979) 'Lessons from the Past : Policy Implications of Historical Fertility Studies', Population and Development Review, 5(2), pp. 217-245.

Kohler, H.-P. (2010) 'Fertility Trends and Implications', in Yi, Z. (ed.) UNESCO-EOLSS Encyclopedia of Life Support Systems: Demography. Ramsey, Isle of Man: Eolss Publishers Co.

Landale, N. and Oropesa, R. (2007) 'Hispanic Familie: Stability and Change', Annual Review of Sociology, 33. doi: 10.1146/annurev.soc.33.040406.131655.

Lebaron, F. and Le Roux, B. (2015) La méhodologie de Pierre Bourdieu en action : espace culturel, espace social et analyse des données. Paris: Dunod.

Lebart, L., Morineau, A. and Piron, M. (1997) Statistique Exploratoire Multidimensionnelle. 2nd edn. Paris: Dunod.

Lee, R. (2003) 'The Demographic Transition: Three Centuries of Fundamental Change', Journal of Economic Perspectives, 17(4), pp. 167-190. doi: 10.1257/089533003772034943.

Lieberson, S. and Horwich, J. (2008) 'Implicaction Analysis: A pragmatic proposal for linking theory and data in the social sciences', Sociological Methodology, 38(1), pp. 1-100. doi: $10.1111 / \mathrm{j} .1467$.

Martine, G. (1996) 'Brazil's Fertility Decline , 1965-95 : A Fresh Look at Key Factors', Population and Development Review, 22(1), pp. 47-75.

Martinez, J. (1998) La transición demográfica y las diferencias sociales de la fecundidad y la mortalidad infantil en Chile. Santiago de Chile.

Mason, K. (1997) 'Explaining fertility transitions', Demography, 34(4), pp. 443-454.

McNicoll, G. (1980) 'Institutional Determinants of Fertility', Population and Development Review, 6(3), pp. 441-462.

Miller, G. (2005) ‘Contraception as development? New evidence from family planning in 
Colombia', National Bureau of Economic Research. doi: 10.1017/CBO9781107415324.004.

Minnesota Population Center (2015) Integrated Public Use Microdata Series, International: Version 6.4, [Machine-readable database].

Miranda-Ribeiro, A. de, Rios-Neto, E. L. G. and Carvalho, J. A. M. de (2009) 'Reconstrução de histórias de nascimentos a partir de dados censitários: uma análise comparativa de duas metodologias', Revista Brasileira de Estudos de População, 26(1), pp. 21-35. doi: 10.1590/S0102-30982009000100003.

Morley, S. (2001) The income distribution problem in Latin America and the Caribbean. United Nations. Available at: http://www.eclac.org/cgi-

bin/getProd.asp?xml=/publicaciones/xml/3/7213/P7213.xml\&xsl=/de/tpl-i/p9f.xsl\&base=/tpl/topbottom.xslt.

Multiple Authors (1986) The Decline of fertility in Europe. 1st edn. Edited by A. Coale and S. Watkins. Princeton, NJ: Princeton University Press.

Multiple Authors (2009) Quantifying theory: Pierre Bourdieu. 1st edn. Edited by K. Robson and C. Sanders. Springer.

Myrskylä, M., Kohler, H.-P. and Billari, F. C. (2009) 'Advances in development reverse fertility declines', Nature, 460(7256), pp. 741-743. doi: 10.1038/nature08230.

Palloni, A. (1990) 'Fertility and Mortality Decline in Latin America', The Annals of the American Academy of Political and Social Science, 510, pp. 126-144. doi:

10.1177/0002716290510001010.

Palloni, A., Hill, K. and Aguirre, G. P. (1996) 'Economic Swings and Demographic Changes in the History of Latin America', Population Studies, 50(1), pp. 105-132. doi:

10.1080/0032472031000149076.

Pardo, C. E. and Del Campo, P. C. (2007) 'Combinación de métodos factoriales y de análisis de conglomerados en R: El paquete FactoClass', Revista Colombiana de Estadistica, 30(2), pp. 231245.

Parrado, E. (2000) 'Social Change, Population Policies, and Fertility Decline in Colombia and Venezuela', Population Research and Policy Review, 19(5), pp. 421-457.

Pesando, L. M. and GFC-team (2019) 'Global Family Change: Persistent Diversity with Development', Population and Development Review, 45(1), pp. 133-168. doi:

10.1111/padr.12209.

Portes, A. (1971) 'Urbanization and politics in Latin America', Social Science Quarterly, 52(3), pp. 697-720.

Portes, A. (1985) 'Latin American Class Structures: Their Composition and Change During the Last Decades', Latin American Research Review, 20(3), pp. 7-39. 
Portes, A. (1989) 'Latin American Urbanization during the Years of the Crisis', Latin American Research Review, 24(3), pp. 7-44.

Portes, A. (2006) 'Institutions and Development: A conceptual Analysis', Population and Development Review, 32(2), pp. 233-262.

Portes, A. and Canak, W. (1981) 'LATIN AMERICA: Social structures and sociology', Annual Review of Sociology, 7, pp. 225-248.

Portes, A. and Hoffman, K. (2003) 'Latin American Class Structures: Their Composition and Change during the Neoliberal Era', Latin American Research Review, 38(1), pp. 41-82. doi: 10.1353/lar.2003.0011.

Rodríguez Vignoli, J. (2004) 'Migracion Interna en America Latina y el Caribe: Estudio Regional del Periodo 1980-2000', Poblacion y Desarrollo. Santiago de Chile, 50.

Le Roux, B. and Rouanet, H. (2004) Geometric Data Analysis: from correspondence analysis to structured data analysis. Dordrecht.

Ryder, N. B. (1965) 'The cohort as a concept in the study of social change', American Sociological Review, 30(6), pp. 843-861. doi: 10.1525/ctx.2009.8.1.20.winter.

Ryder, N. B. (1983) 'Fertility and family structure', Population Bulletin of the United Nations, (15).

Savage, M. et al. (2013) 'A New Model of Social Class? Findings from the BBC's Great British Class Survey Experiment', Sociology, 47(2), pp. 219-250. doi: 10.1177/0038038513481128.

Schkolnik, S. and Chackiel, J. (2004) Less advanced sectors in the Latin American fertility transition.

Schmertmann, C., Potter, J. and Cavenaghi, S. (2005) 'Exploratory Analysis of Spatial Patterns in Brazil's Fertility Transition', Population Research and Policy Review, 27(1), pp. 1-15. doi: $10.1007 / \mathrm{sl}$.

Schneider, J. and Schneider, P. (1996) Festival of the Poor. Fertility Decline and the Ideology of Class. 1st edn. Tucson: The university of Arizona press.

Schockaert, I. (2005) 'Travail féminin et fécondité en Amérique latine', Population, 60(1), pp. 157-178. doi: 10.3917/popu.501.0157.

Shenk, M. K. et al. (2013) 'A model comparison approach shows stronger support for economic models of fertility decline', Proceedings of the National Academy of Sciences, 110(20), pp. 8045-8050. doi: 10.1073/pnas.1217029110.

Skirbekk, V. (2008) 'Fertility trends by social status', Demographic Research, 18, pp. 145-180. doi: 10.4054/DemRes.2008.18.5.

Smith, H. (2013) 'Research Design: Toward a Realistic Role for Causal Analysis', in Handbook 
of Causal Analysis for Social Research. Springer, pp. 45-73. doi: 10.1007/978-94-007-6094-3.

Svallfors, S. and Billingsley, S. (2019) 'Conflict and Contraception in Colombia', Studies in Family Planning, 50(2), pp. 87-112. doi: 10.1111/sifp.12087.

Szreter, S. (1996) Fertility, class and gender in Britain, 1860-1940. 1st edn. Cambridge: Cambridge University Press. doi: 10.1017/CBO9780511582240.

Torche, F. (2014) 'Intergenerational Mobility and Inequality: The Latin American Case', Annual Review of Sociology, 40(1), pp. 619-642. doi: 10.1146/annurev-soc-071811-145521.

Torrado, S. (1981) 'Sobre los conceptos de "estrategias familiares de vida" y "procesos de reproduccion de la fuerza de trabajo": notas teorico-metodologicas', Demografía y economía, 15(2), pp. 204-233.

Vandenberghe, F. (1999) “The real is relational”: An epistemological analysis of Pierre Bourdieu's Generative Structuralism', Sociological Theory, 17(1), pp. 32-67.

Vidal-Zeballos, D. (1994) 'Social Strata and its Influence on the determinants of reproductive behaviour in Bolivia', Demographic and Health Survey Working papers, (12), pp. 1-58.

Viveros Vigoya, M. (2015) 'L'intersectionnalité au prisme du féminisme latino-américain', Raisons politiques, 58(2), pp. 39-54. doi: 10.3917/rai.058.0039.

De Vos, S. (1995) Household Composition in Latin America. 1st edn. New York: Plenum Press.

Walby, S., Armstrong, J. and Strid, S. (2012) 'Intersectionality: Multiple inequalities in social theory', Sociology, 46(2), pp. 224-240. doi: 10.1177/0038038511416164.

Williamson, J. G. (2010) 'Five centuries of Latin American income inequality', Revista de Historia Económica / Journal of Iberian and Latin American Economic History, 28(02), pp. 227252. doi: $10.1017 / \mathrm{S} 0212610910000078$.

Wright, E. O. (2015) Understanding Class. 1st edn. New York: Verso. 
Figure I. Reproductive lifespans of women in the analytical sample and exact year of data collection

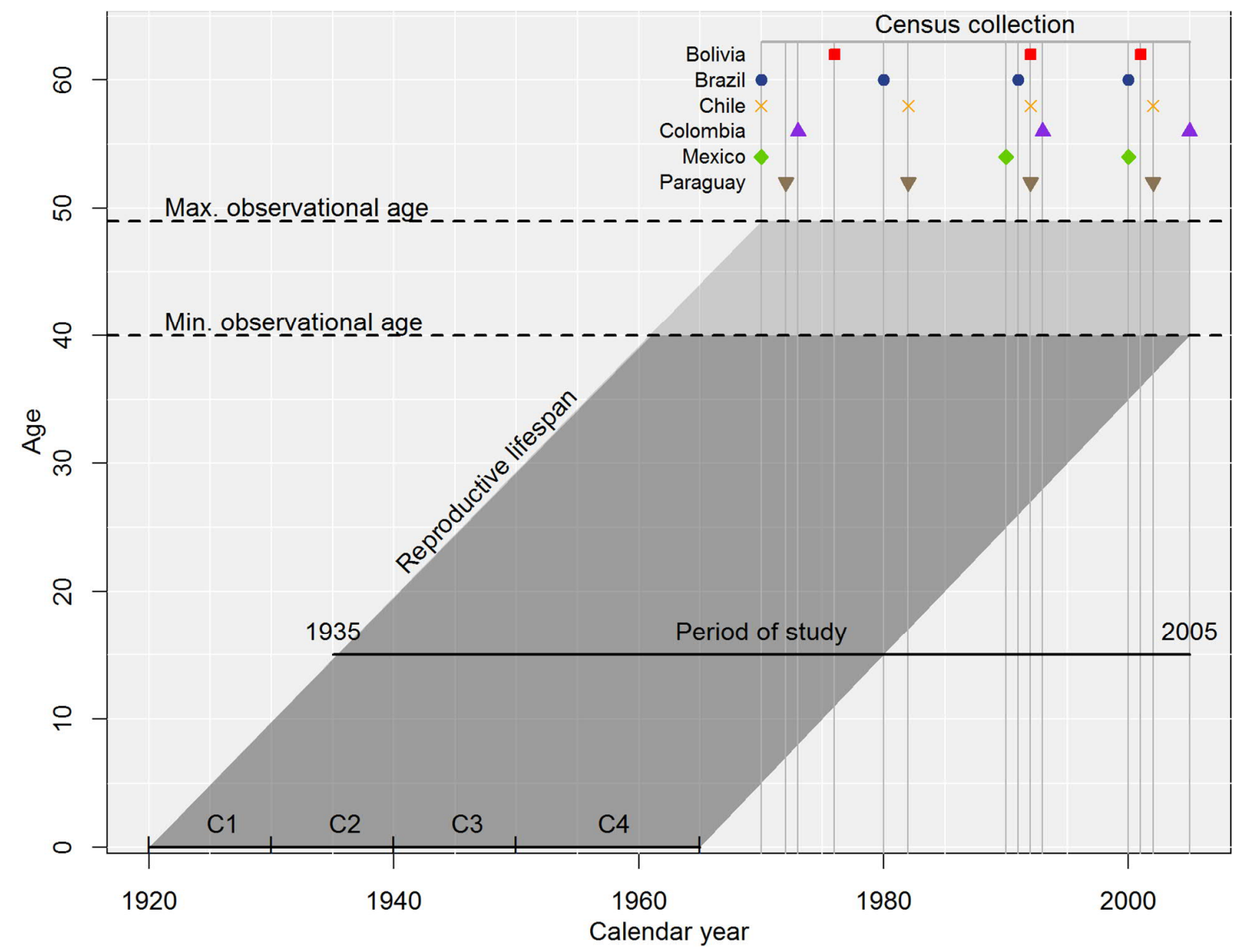

Note: The dark-shaded-grey parallelogram represents the life span of the birth cohorts included in this study. Vertical grey lines indicate the exact year of the census collection. Because the time between censuses varies within and between countries, the location of the cohorts is approximate. 
Table I. Sample size by country and birth cohort

\begin{tabular}{|c|c|c|c|c|c|}
\hline \multirow[b]{2}{*}{ Country } & \multicolumn{4}{|c|}{ Birth cohort } & \multirow[b]{2}{*}{ Total } \\
\hline & $\begin{array}{c}\text { C1 } \\
1920-29\end{array}$ & $\begin{array}{c}\mathrm{C2} \\
1930-39\end{array}$ & $\begin{array}{c}\text { C3 } \\
1940-49\end{array}$ & $\begin{array}{c}C 4 \\
1950-65\end{array}$ & \\
\hline Bolivia & 12,135 & & 11,535 & 16,532 & 40,202 \\
\hline Brazil & 145,084 & 170,883 & 262,189 & 338,384 & 916,540 \\
\hline Chile & 23,869 & 28,863 & 41,641 & 60,224 & 154,597 \\
\hline Colombia & 32,977 & & 60,119 & 53,259 & 146,355 \\
\hline Mexico & 10,760 & & 192,566 & 268,736 & 472,062 \\
\hline Paraguay & 6,004 & 7,149 & 10,991 & 14,600 & 38,744 \\
\hline Total & 230,829 & 206,895 & 579,041 & 751,735 & $1,768,500$ \\
\hline
\end{tabular}

Note: The sample includes native born women ages 40 to 49 living with a partner or spouse at the time of the census and with complete information on all socioeconomic and fertility-related variables. 
Table II. Birth histories distribution by parity level, completeness, and matching score

\begin{tabular}{|c|c|c|c|c|c|c|c|}
\hline \multirow{4}{*}{ Parity level } & \multicolumn{6}{|c|}{ Birth histories } & \multirow{4}{*}{ Total } \\
\hline & \multirow{3}{*}{ Complete } & \multicolumn{5}{|c|}{ Incomplete } & \\
\hline & & \multicolumn{5}{|c|}{ Relative matching score (\%) } & \\
\hline & & Zero & $(0$ to 25$]$ & (25 to 50] & (50 to 75$]$ & (75 to 100$]$ & \\
\hline \multirow[t]{2}{*}{$\overline{\text { Zero }}$} & 57,672 & - & - & - & - & - & 57,672 \\
\hline & 100 & - & - & - & - & - & 100 \\
\hline \multirow[t]{2}{*}{ One } & 91,370 & 19,588 & - & - & - & - & 110,958 \\
\hline & 82 & 18 & - & - & - & - & 100 \\
\hline \multirow[t]{2}{*}{ Two } & 217,649 & 23,287 & - & - & - & 55,576 & 296,512 \\
\hline & 73 & 8 & - & - & - & 19 & 100 \\
\hline \multirow[t]{2}{*}{ Three } & 183,711 & 19,100 & - & 2,182 & - & 122,921 & 327,914 \\
\hline & 56 & 6 & - & 1 & - & 37 & 100 \\
\hline \multirow[t]{2}{*}{ Four } & 89,068 & 12,223 & - & 1,663 & 9,225 & 121,148 & 233,327 \\
\hline & 38 & 5 & - & 1 & 4 & 52 & 100 \\
\hline \multirow[t]{2}{*}{ Five to six } & 73,150 & 13,482 & 109 & 4,600 & 36,169 & 177,218 & 304,728 \\
\hline & 24 & 4 & 0 & 2 & 12 & 58 & 100 \\
\hline \multirow[t]{2}{*}{ Seven and more } & 40,938 & 28,279 & 1,748 & 17,400 & 95,804 & 253,220 & 437,389 \\
\hline & 9 & 6 & 0 & 4 & 22 & 58 & 100 \\
\hline Total & 753,558 & 115,959 & 1,857 & 25,845 & 141,198 & 730,083 & $1,768,500$ \\
\hline$(\%)$ & 42.6 & 6.6 & 0.1 & 1.5 & 8.0 & 41.3 & 100 \\
\hline
\end{tabular}

Note: A birth history is assumed to be complete when the number of children ever born reported by a woman equals the number of own children present in the household at the time of the census. Information on children ever born come from the variable: CHBORN. Own children are identified using the variables: MOMLOC and STEPMOM. Birth misreporting is ignored because it is unlikely to be consequential for the results. 
Figure II. Fertility indicators by country and birth cohort
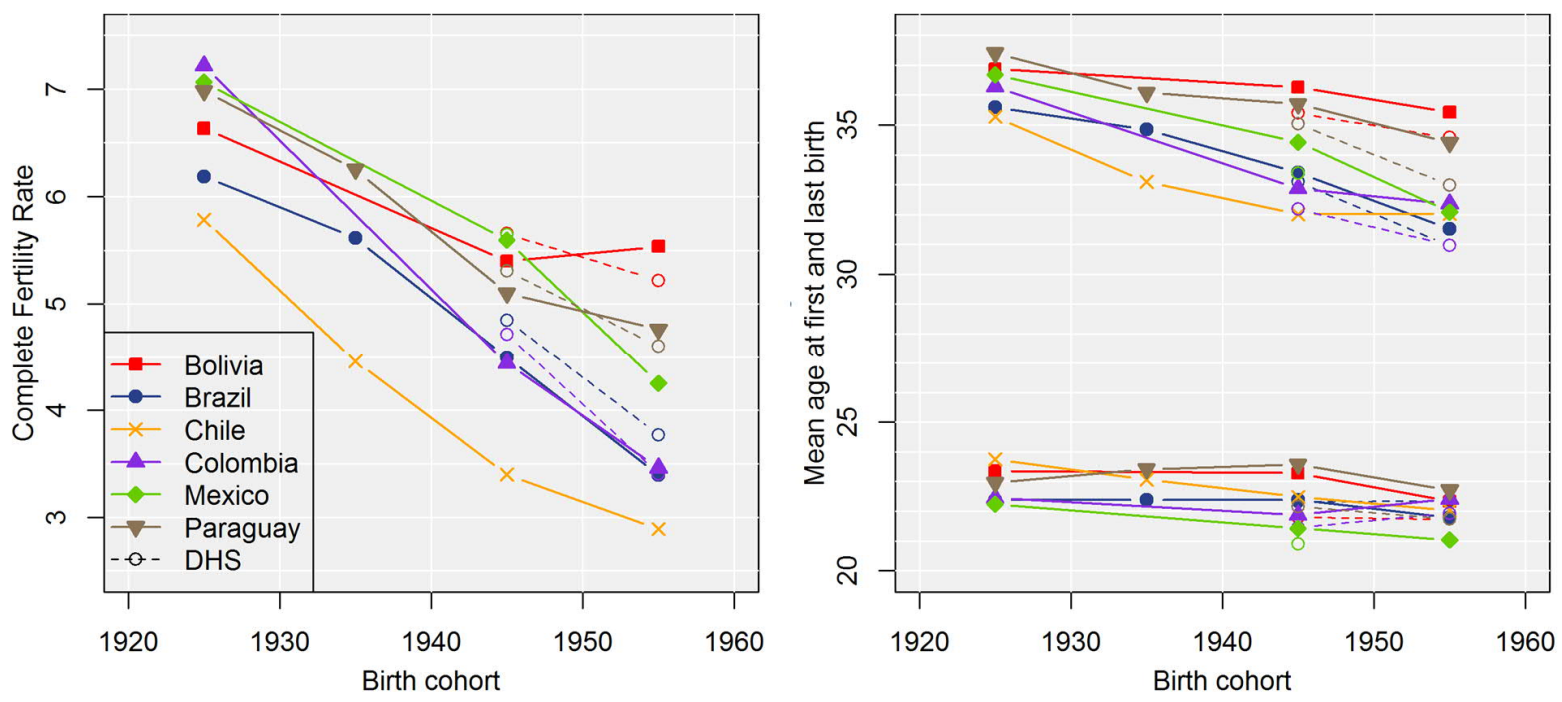

Note: Census data from IPUMS-I (solid lines) and Demographic and Health Surveys (DHS, dotted lines). DHS figures are obtained using full retrospective information on childbearing. 
Table III. Socioeconomic profiles for two cohorts in six Latin American countries

\begin{tabular}{|c|c|c|c|c|c|c|c|c|c|c|c|c|c|}
\hline & \multirow{2}{*}{$\begin{array}{r}\text { Country } \\
\text { Birth cohort }\end{array}$} & \multicolumn{2}{|c|}{ Bolivia } & \multicolumn{2}{|c|}{ Brazil } & \multicolumn{2}{|c|}{ Chile } & \multicolumn{2}{|c|}{ Colombia } & \multicolumn{2}{|c|}{ Mexico } & \multicolumn{2}{|c|}{ Paraguay } \\
\hline & & $\mathrm{C} 1$ & $\mathrm{C} 4$ & $\mathrm{C} 1$ & $\mathrm{C} 4$ & $\mathrm{C} 1$ & $\mathrm{C} 4$ & $\mathrm{C} 1$ & $\mathrm{C} 4$ & $\mathrm{C} 1$ & $\mathrm{C} 4$ & $\mathrm{C} 1$ & $\mathrm{C} 4$ \\
\hline \multicolumn{14}{|c|}{ Woman's educational attainment } \\
\hline No education & & 87 & 51 & 92 & 56 & 53 & 15 & 70 & 35 & 80 & 37 & 83 & 42 \\
\hline Primary & & 10 & 25 & 4 & 18 & 38 & 46 & 27 & 39 & 18 & 44 & 12 & 40 \\
\hline Secondary & & 3 & 19 & 4 & 18 & 8 & 35 & 3 & 17 & 2 & 12 & 4 & 14 \\
\hline University & & -- & 4 & -- & 8 & -- & 5 & -- & 9 & -- & 7 & -- & 5 \\
\hline \multicolumn{14}{|c|}{ Man's educational attainment } \\
\hline No education & & 79 & 34 & 90 & 58 & 48 & 14 & 67 & 39 & 77 & 33 & 80 & 41 \\
\hline Primary & & 16 & 36 & 5 & 18 & 40 & 43 & 27 & 36 & 19 & 42 & 14 & 41 \\
\hline Secondary & & 6 & 22 & 5 & 15 & 12 & 36 & 3 & 14 & 4 & 11 & 6 & 12 \\
\hline University & & -- & 9 & -- & 9 & -- & 8 & 2 & 10 & -- & 14 & -- & 6 \\
\hline \multicolumn{14}{|c|}{ Couple's place of residence } \\
\hline Capital city & & 13 & 20 & 28 & 33 & 48 & 55 & 14 & 12 & 16 & 11 & 18 & 10 \\
\hline Rural areas & & 66 & 36 & 43 & 18 & 25 & 11 & 39 & 33 & 40 & 19 & 62 & 40 \\
\hline Urban areas & & 21 & 45 & 29 & 49 & 28 & 34 & 47 & 55 & 44 & 70 & 20 & 50 \\
\hline \multicolumn{14}{|c|}{ Ownership of the dwelling } \\
\hline Owned & & 83 & 76 & 67 & 81 & 59 & 77 & 67 & 65 & 70 & 86 & 88 & 88 \\
\hline Renting & & 9 & 15 & 16 & 10 & 21 & 14 & 21 & 23 & 30 & 14 & 5 & 5 \\
\hline Provided & & 8 & 9 & 6 & 9 & 20 & 10 & 9 & 9 & -- & -- & -- & -- \\
\hline Occupied & & -- & -- & 12 & -- & -- & -- & 3 & 4 & -- & -- & 6 & 6 \\
\hline \multicolumn{14}{|l|}{ Electricity | Television } \\
\hline Yes | Yes & & -- & 63 & 29 & 90 & 90 & 96 & -- & 77 & 36 & 91 & 9 & 80 \\
\hline Yes $\mid$ No & & -- & 8 & 20 & 5 & 5 & 2 & -- & 17 & 27 & 6 & 10 & 13 \\
\hline No $\mid$ No & & -- & 29 & 50 & 5 & 5 & 2 & -- & 6 & 37 & 3 & 81 & 7 \\
\hline Yes |n.a. & & 30 & -- & -- & -- & -- & -- & 61 & -- & -- & -- & -- & -- \\
\hline No|n.a. & & 70 & -- & -- & -- & -- & -- & 39 & -- & -- & -- & -- & -- \\
\hline \multicolumn{14}{|l|}{ Water supply } \\
\hline Piped exclusive & & 13 & 40 & 37 & 85 & 64 & 94 & 58 & 81 & 44 & 67 & 7 & 45 \\
\hline Piped shared & & 21 & 35 & 5 & 5 & 16 & 4 & 10 & -- & 22 & 24 & 5 & 26 \\
\hline No piped water & & 67 & 26 & 58 & 9 & 20 & 2 & 32 & 19 & 34 & 8 & 88 & 29 \\
\hline \multicolumn{14}{|c|}{ Woman's position at work } \\
\hline Self-account & & 8 & 34 & 3 & 14 & 4 & 7 & 3 & 6 & 3 & 11 & 8 & 20 \\
\hline Employee(r) & & 4 & 14 & 6 & 30 & 8 & 29 & 5 & 25 & 4 & 19 & 4 & 18 \\
\hline Inactive & & 88 & 51 & 91 & 56 & 88 & 64 & 93 & 70 & 92 & 70 & 87 & 62 \\
\hline \multicolumn{14}{|l|}{ Man's position at work } \\
\hline Employer & & 2 & 5 & 4 & 6 & 4 & 6 & 16 & -- & 8 & 5 & 4 & 6 \\
\hline Self-account & & 70 & 57 & 50 & 40 & 25 & 22 & 28 & 24 & 35 & 33 & 69 & 60 \\
\hline Employee(r) & & 28 & 38 & 46 & 55 & 70 & 72 & 56 & 76 & 57 & 62 & 27 & 35 \\
\hline \multicolumn{14}{|l|}{ Man's economic sector } \\
\hline Agriculture & & 65 & 35 & 49 & 22 & 30 & 16 & 44 & 36 & 49 & 20 & 61 & 34 \\
\hline Manufacturing & & 7 & 11 & 11 & 13 & 18 & 15 & 14 & 7 & 16 & 17 & 11 & 11 \\
\hline Construction & & 6 & 11 & 8 & 12 & 10 & 12 & 8 & 9 & 6 & 12 & 6 & 12 \\
\hline Services & & 12 & 22 & 14 & 30 & 18 & 30 & 15 & 32 & 14 & 28 & 10 & 18 \\
\hline Sales & & 4 & 12 & 12 & 14 & 15 & 17 & 12 & 9 & 10 & 14 & 8 & 18 \\
\hline Clerical and education & & 5 & 9 & 7 & 9 & 9 & 10 & 7 & 6 & 5 & 9 & 4 & 7 \\
\hline
\end{tabular}

Note: All values are column percentages. Numbers add up to 100 within each variable. C1: 1920-29, C4: 1950-65 as in Figure I. Variables' categories correspond exactly to those used in the Multiple Correspondence Analyses. 
Figure III. Proportion of retained variance across factorial dimensions
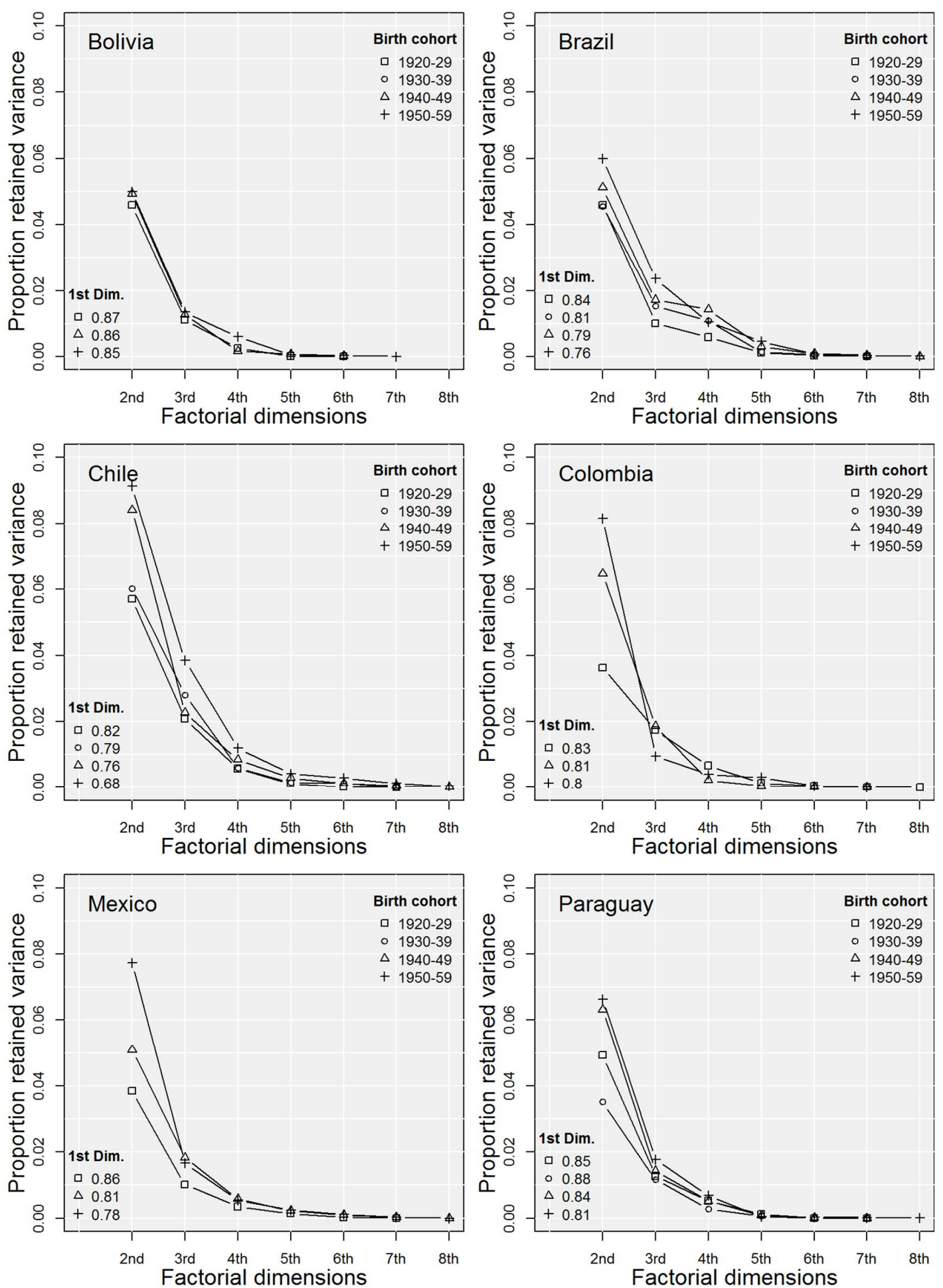

Note: The number of factorial dimensions equals the number of categories (Table III) minus the number of variables (9). Proportions are calculated according to Greenacre and Blasius' (2006) formula. 
Figure IV. Proportion of explained variance for several numbers of clusters
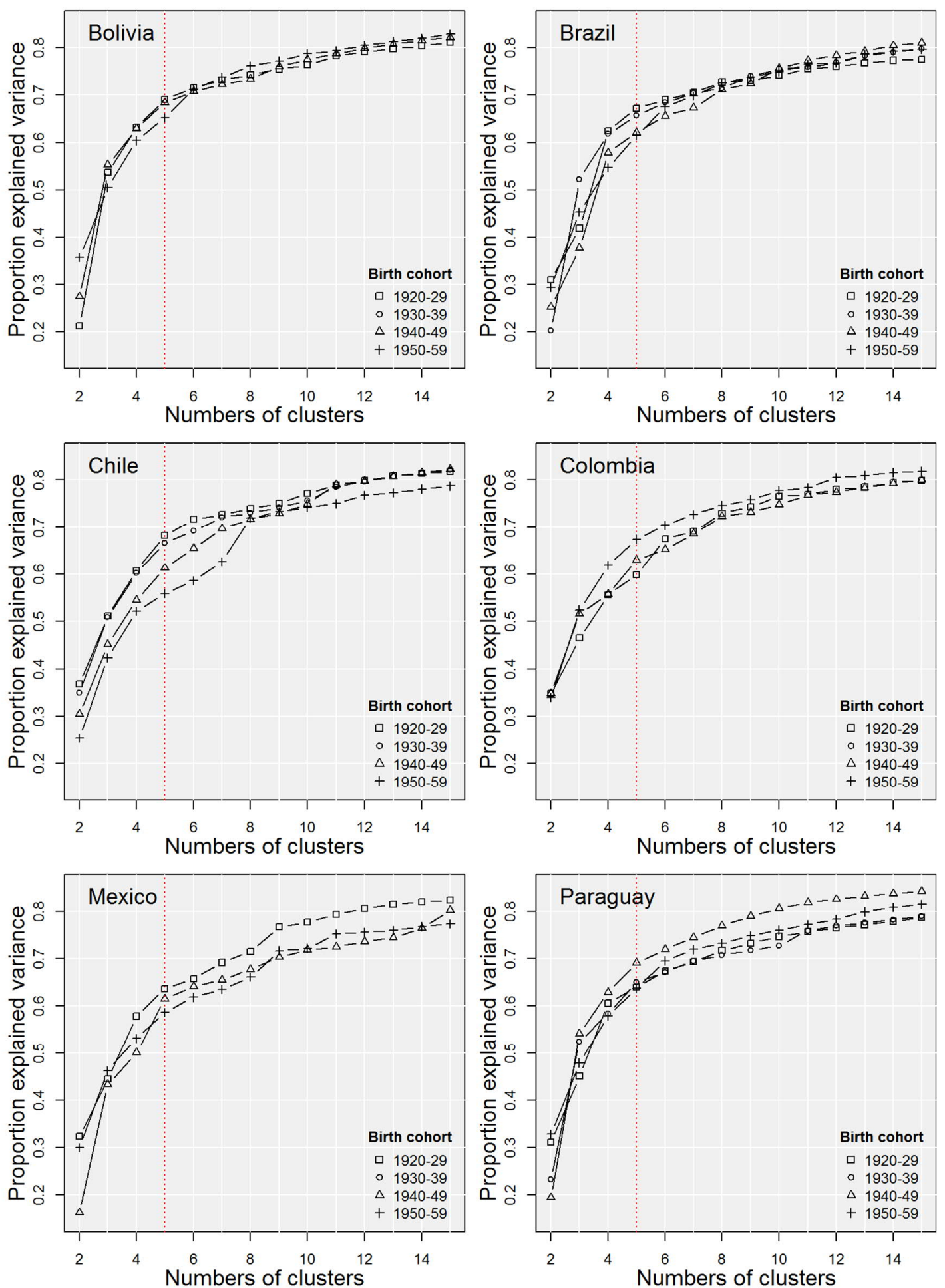

Note: The proportion of explained variance is computed as the ratio of the sum of squared distances within clusters and the total sum of squared distances according to Studer et al. (2011) 
Table IV. Marginal distribution of probable social class for the first and the last cohort

\begin{tabular}{|c|c|c|c|c|c|c|c|c|c|c|c|c|}
\hline \multirow{3}{*}{$\begin{array}{c}\text { Probable } \\
\text { social class } \\
\text { Birth cohort }\end{array}$} & \multicolumn{12}{|c|}{ Country } \\
\hline & \multicolumn{2}{|c|}{ Bolivia } & \multicolumn{2}{|c|}{ Brazil } & \multicolumn{2}{|c|}{ Chile } & \multicolumn{2}{|c|}{ Colombia } & \multicolumn{2}{|c|}{ Mexico } & \multicolumn{2}{|c|}{ Paraguay } \\
\hline & $\mathrm{C} 1$ & $\mathrm{C} 4$ & $\mathrm{C} 1$ & $\mathrm{C} 4$ & $\mathrm{C} 1$ & $\mathrm{C} 4$ & $\mathrm{C} 1$ & $\mathrm{C} 4$ & $\mathrm{C} 1$ & $\mathrm{C} 4$ & $\mathrm{C} 1$ & $\mathrm{C} 4$ \\
\hline Lowest & 61.0 & 32.7 & 45.7 & 10.7 & 24.1 & 10.9 & 39.5 & 29.8 & 37.0 & 6.8 & 61.8 & 17.9 \\
\hline Low & 12.5 & 22.3 & 20.6 & 30.4 & 23.4 & 37.0 & 13.2 & 13.4 & 30.2 & 22.9 & 19.9 & 25.1 \\
\hline Lower-middle & 11.3 & 23.4 & 17.4 & 28.2 & 17.6 & 19.6 & 22.0 & 29.5 & 12.7 & 32.5 & 8.9 & 34.7 \\
\hline Upper-middle & 10.9 & 13.7 & 10.5 & 19.4 & 26.0 & 23.1 & 19.5 & 16.9 & 15.4 & 22.2 & 5.0 & 15.7 \\
\hline Upper & 4.3 & 8.0 & 5.7 & 11.4 & 8.8 & 9.3 & 5.7 & 10.3 & 4.7 & 15.7 & 4.4 & 6.6 \\
\hline Total & 100 & 100 & 100 & 100 & 100 & 100 & 100 & 100 & 100 & 100 & 100 & 100 \\
\hline
\end{tabular}

Note: All values are column percentages. C1: 1920-29, C4: 1950-65 as in Figure I 
Figure V. Social spaces, probable social classes, and complete fertility across cohorts

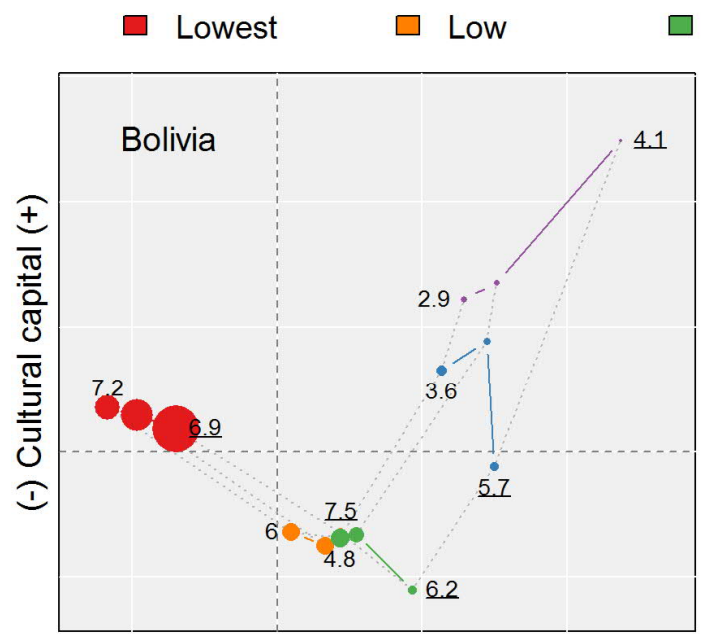

(-) Economic capital (+)

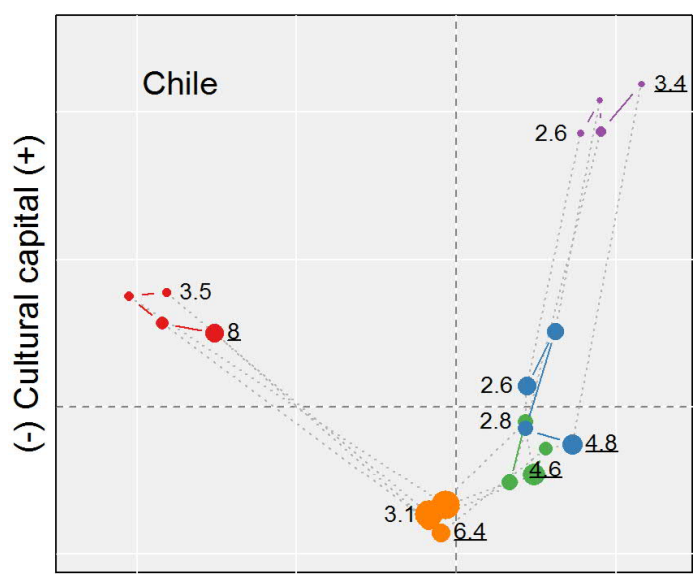

(-) Economic capital (+)

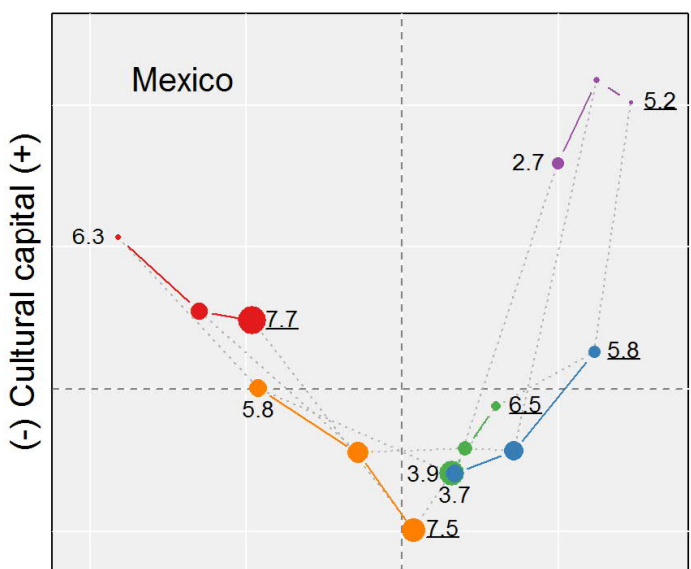

(-) Economic capital (+)
Lower-middle $\square$ Upper-middle $\square$ Upper

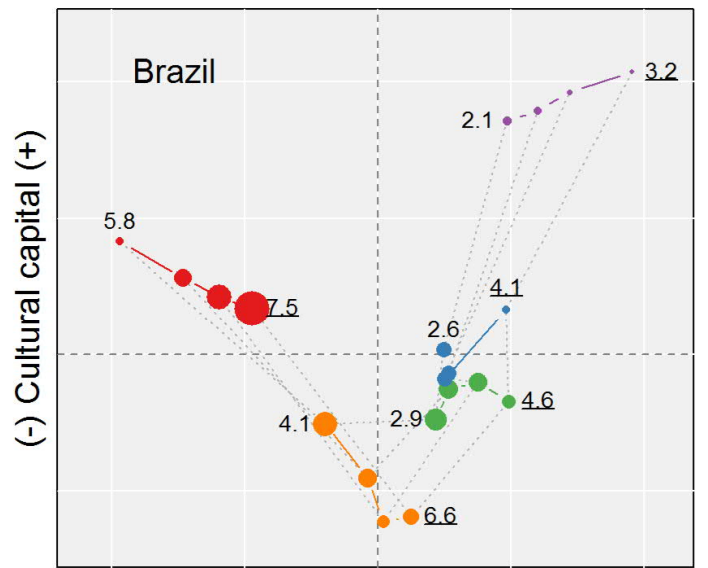

(-) Economic capital (+)

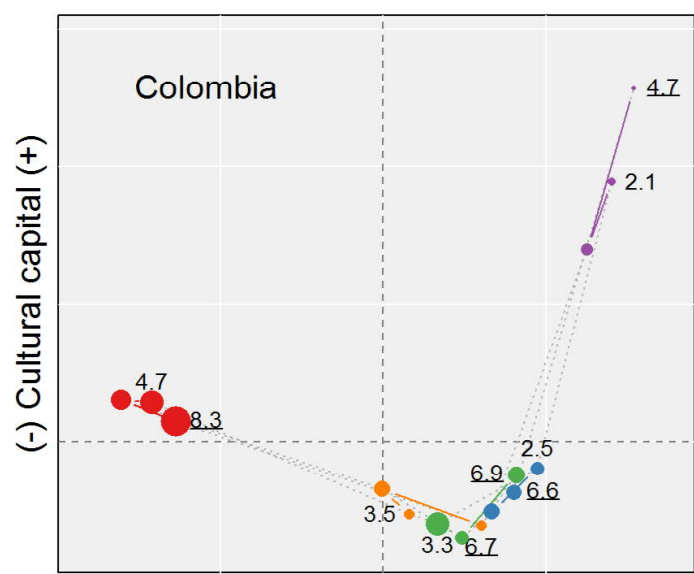

$(-)$ Economic capital (+)

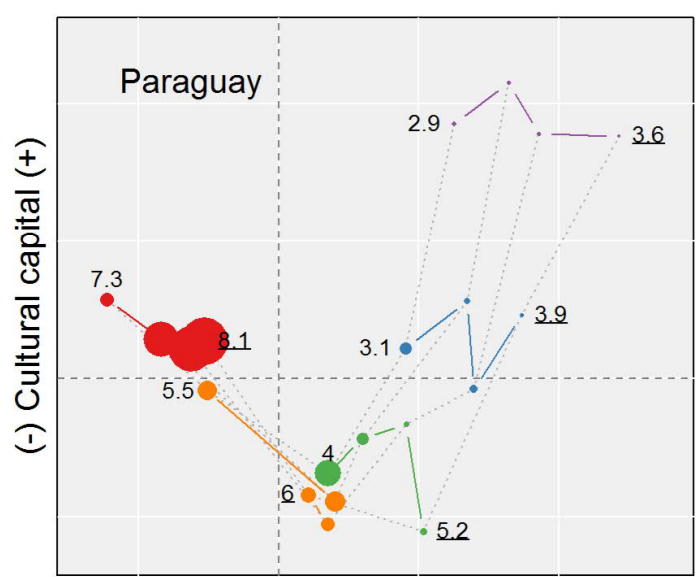

(-) Economic capital (+)

Note: The point's size is proportional to the number of couples. Dotted lines represent between-class social distances. Background lines are separated by one standard deviation. Numbers correspond to the complete fertility rate of the first (underlined) and last cohort. 
Table V. Mean age at first and last birth by probable social class for the first and last cohort

\begin{tabular}{|c|c|c|c|c|c|c|c|c|c|c|}
\hline \multirow{3}{*}{$\begin{array}{l}\text { Country } \\
\text { Birth cohort }\end{array}$} & \multicolumn{10}{|c|}{ Probable social class } \\
\hline & \multicolumn{2}{|c|}{ Lowest } & \multicolumn{2}{|c|}{ Low } & \multicolumn{2}{|c|}{ Lower-middle } & \multicolumn{2}{|c|}{ Uppe r-middle } & \multicolumn{2}{|c|}{ Upper } \\
\hline & $\mathrm{C} 1$ & $\mathrm{C} 4$ & $\mathrm{C} 1$ & $\mathrm{C} 4$ & $\mathrm{C} 1$ & $\mathrm{C} 4$ & $\mathrm{C} 1$ & $\mathrm{C} 4$ & $\mathrm{C} 1$ & $\mathrm{C} 4$ \\
\hline \multicolumn{11}{|l|}{ Bolivia } \\
\hline First birth $^{1}$ & 27.6 & 27.5 & 27.2 & 25.3 & 26.3 & 24.5 & 25.0 & 25.8 & 26.5 & 26.7 \\
\hline First birth ${ }^{2}$ & 24.1 & 22.9 & 23.6 & 22.6 & 24.1 & 22.4 & 23.9 & 23.6 & 25.1 & 25.0 \\
\hline First birth ${ }^{3}$ & 24.1 & 23.4 & 23.9 & 22.4 & 23.8 & 22.0 & 23.2 & 23.3 & 24.7 & 24.8 \\
\hline Last birth & 37.6 & 37.8 & 37.3 & 35.6 & 36.0 & 34.1 & 34.6 & 33.3 & 33.6 & 33.2 \\
\hline \multicolumn{11}{|l|}{ B razil } \\
\hline First birth $^{1}$ & 25.4 & 25.7 & 25.6 & 25.0 & 25.4 & 25.5 & 25.1 & 25.4 & 26.5 & 27.3 \\
\hline First birth ${ }^{2}$ & 22.8 & 21.4 & 22.9 & 20.6 & 23.2 & 22.1 & 23.2 & 22.4 & 25.1 & 25.8 \\
\hline First birth ${ }^{3}$ & 22.4 & 21.2 & 22.5 & 20.5 & 22.9 & 22.1 & 23.0 & 22.4 & 25.0 & 25.8 \\
\hline Last birth & 37.1 & 34.5 & 36.1 & 31.7 & 33.7 & 30.9 & 32.7 & 30.5 & 32.8 & 31.4 \\
\hline \multicolumn{11}{|l|}{ Chile } \\
\hline First birth $^{1}$ & 26.4 & 25.7 & 26.5 & 25.1 & 26.1 & 25.7 & 25.8 & 26.3 & 26.5 & 27.5 \\
\hline First birth ${ }^{2}$ & 24.5 & 20.6 & 24.5 & 21.4 & 24.0 & 22.5 & 24.3 & 23.5 & 24.3 & 25.2 \\
\hline First birth $^{3}$ & 24.1 & 20.5 & 24.0 & 21.4 & 23.6 & 22.4 & 23.8 & 23.5 & 24.1 & 25.2 \\
\hline Last birth & 37.7 & 31.7 & 36.3 & 31.8 & 33.8 & 32.0 & 34.0 & 32.2 & 32.4 & 33.1 \\
\hline \multicolumn{11}{|l|}{ Colombia } \\
\hline First birth ${ }^{1}$ & 25.6 & 25.5 & 25.8 & 25.1 & 24.9 & 25.3 & 24.8 & 26.5 & 25.4 & 28.8 \\
\hline First birth ${ }^{2}$ & 23.1 & 21.5 & 23.8 & 21.8 & 23.8 & 21.9 & 23.4 & 24.2 & 24.3 & 26.6 \\
\hline First birth ${ }^{3}$ & 22.4 & 21.3 & 23.2 & 21.6 & 23.1 & 21.8 & 22.8 & 24.2 & 23.9 & 26.5 \\
\hline Last birth & 37.3 & 33.3 & 36.4 & 31.7 & 36.0 & 31.7 & 35.3 & 32.0 & 33.5 & 33.1 \\
\hline \multicolumn{11}{|l|}{ Mexico } \\
\hline First birth $^{1}$ & 25.4 & 25.3 & 25.3 & 24.6 & 25.0 & 24.2 & 25.0 & 24.2 & 25.8 & 26.3 \\
\hline First birth ${ }^{2}$ & 22.6 & 20.7 & 23.1 & 20.4 & 23.7 & 21.1 & 24.0 & 21.1 & 24.8 & 24.3 \\
\hline First birth ${ }^{3}$ & 22.1 & 20.4 & 22.5 & 20.2 & 23.0 & 20.9 & 23.4 & 21.0 & 24.3 & 24.2 \\
\hline Last birth & 37.4 & 34.8 & 37.1 & 33.4 & 35.8 & 31.4 & 35.4 & 31.2 & 34.6 & 31.8 \\
\hline \multicolumn{11}{|l|}{ Paraguay } \\
\hline First birth ${ }^{1}$ & 25.9 & 25.4 & 26.1 & 25.1 & 26.1 & 25.0 & 25.7 & 26.2 & 26.8 & 27.2 \\
\hline First birth ${ }^{2}$ & 23.7 & 22.8 & 24.4 & 22.8 & 24.6 & 23.4 & 25.0 & 25.0 & 26.3 & 26.2 \\
\hline First birth ${ }^{3}$ & 23.1 & 22.4 & 23.9 & 22.5 & 24.0 & 23.1 & 24.5 & 24.9 & 26.0 & 26.1 \\
\hline Last birth & 38.6 & 36.7 & 36.1 & 34.8 & 35.5 & 33.6 & 33.6 & 33.4 & 34.2 & 33.5 \\
\hline
\end{tabular}

Note: ${ }^{1}$ age at first birth based on the age of the oldest child living in the household (strongly upward bias), ${ }^{2}$ age at first birth among women with complete birth histories (upward bias due to selection), ${ }^{3}$ imputed age at first birth using matching process (reduced bias, still present) 